\title{
An Introduction to the Theory of Tachyons
}

\author{
Ricardo S. Vieira* \\ Departamento de Física, Universidade Federal de São Carlos (UFSCar), São Carlos, Brasil
}

\begin{abstract}
The theory of relativity, which was proposed in the beginning of the 20th century, applies to particles and frames of reference whose velocity is less than the velocity of light. In this paper we shall show how this theory can be extended to particles and frames of reference which move faster than light.
\end{abstract}

\section{The need for a theory of tachyons}

Scientists at the European Organization for Nuclear Research (CERN) recently reported the results of an experiment [1] on which faster than light neutrinos were probably detected. Coincidentally, about a week before the divulgation of this result, I was fortunate to present at the 7th UFSCar Physics Week 2] a lecture precisely on the subject of tachyons (the name given in theoretical physics to faster than light particles). Students and Professors were very interested on this lecture, specially after the news discussed above. I have been encouraged since then to write a paper about the ideas presented on that occasion, which constitute the present text.

Regardless of the results presented in [1] are correct or not, we point out that there are other experimental evidences for existence of superluminal phenomena in nature [3]. Moreover, the theory of tachyons could provide a better understanding of the theory of relativity as well as some issues of quantum mechanics and we believe that these arguments are enough for one to try to formulate an extended theory of relativity, which applies to faster than light phenomena, particles and reference frames. Attempts to extend the theory of relativity have been, of course, proposed by many scientists, although the original sources are not easily accessible (in fact, only recently I had knew about

\footnotetext{
*E-mail: rsvieira@df.ufscar.br.
}

these works). Among the formulations proposed, we highlight the works of Recami and collaborators [4, whose results coincide mostly with those who will be presented here. Reference [4] is a review on the subject, where the interested reader will find a vast amount of references and may also get more details about the theory, besides topics which will not be discussed here (e.g., the tachyon electrodynamics).

For an extended theory of relativity, we mean a theory which applies to particles and frames of reference moving with a velocity greater than $c$ - the speed of light in vacuum -, and also to particles and reference frames "moving" back in time. In particular it is necessary to extend the Lorentz transformations for such frames. Although we have no problem at all to extend the Lorentz transformations in a two-dimensional universe, $(x, t)$, we meet with certain difficulties when we try to extend them in a universe of four dimensions, $(x, y, z, t)$. The reasons why this happens will be commented in section 10. Finally, in section 11] we shall show that in a six-dimensional world (3 space-like dimensions and other 3 time-like ones), we can make those difficulties to disappear and therefore that becomes possible, in this six-dimensional universe, to extend the Lorentz transformations in agreement with the usual principles of relativity.

One of the reasons which makes the theory of tachyons almost unknown is the (equivocated) belief that the theory of relativity forbids the existence of faster than light particles, and that the light speed represents an upper limit for the propagation of any phenomena in nature. The argument commonly used to prove this statement is, as stated by the theory of relativity, that no particle whatsoever can be accelerated to reach or to exceed the speed of light, since this would require spending an infinite amount of energy. This is not wrong, but is also not completely correct. Indeed, this argument ignores the possibility of these particles have been created at the same time as the 
Big-Bang. In this way nobody had to speed them up - they just were born already with a greater than light speed.

Moreover, we can not rule out the possibility that such particles might be created through some quantum process, analogous for instance to the process of creation of particle-antiparticle pairs.

Finally, if we associate a complete isotropy and homogeneity to the space-time, then it follows that none of their directions should be privileged with respect to the others and thus the existence of faster than light particles would naturally be expected instead of be regarded as surprising. It is not the possibility of existence of tachyons which requires explanation, on the contrary, an explanation must to be given in the case of these particles do not exist.

\section{On the space-time structure}

As is known, the formulation of the theory of relativity was due to the efforts of several scientists (e.g., Lorentz, Poincaré, Einstein, Minkowski etc.). The geometric description of the relativity theory - the so-called spacetime theory - in its turn, was first proposed by Poincaré [5] in 1905 and after independently by Minkowski [6] in 1909, where a more accessible and detailed presentation of the subject was presented.

This geometric description, which contains the very essence of the theory of relativity, may be grounded on the following statements, or postulates 1 :

1. The universe is a four-dimensional continuum three of them are associated with the usual spatial dimensions $X, Y$ and $Z$, while the other one it is associated with the time dimension;

2. The space-time is homogeneous and isotropic;

3. The geometry of the universe is hyperboliccircular. In the purely spatial plans, $X Y, Y Z$ and $Z X$ the geometry is circular (i.e., euclidean), while in the plans involving the time dimension, namely, $T X, T Y$ and $T Z$, the geometry is hyperbolic (i.e., pseudo-euclidean).

In terms of the Poincaré-Minkowski description of space-time, any inertial frame can be represented by an appropriate coordinate system, which we shall call

\footnotetext{
${ }^{1}$ The influence of gravity will be explicitly neglected in this text
}

inertial coordinate system. The movement of a particle can be represented by a continuous curve - a straight line in the case of a free particle -, which we shall call the world-line of the particle. In particular, the velocity of a particle with respect to a given frame of reference, say $R$, is determined by the direction of the particle's world-line with respect to the time-axis of the inertial coordinate system associated with $R$. Similarly, the relative velocity $v$ between two frames $R$ and $R^{\prime}$ is determined by the direction of the time-axis of $R^{\prime}$ with respect to that of $R$ and a change of reference turns out to be, in this geometric description, a mere hyperbolic rotation 2 of the coordinate axes.

From these assumptions presented above, the theory of relativity can be fully formulated. In particular, we point out that from these assumptions we can deduce the principle of invariance of the speed of light (at least in two dimensions). Indeed, the simple fact that the geometry of space-time is hyperbolic implies the existence of a special value of velocity which appears to be the same to all inertial frames, that is, whose value does not change when one go from a inertial frame to another. We can convince ourselves of this noting that in a hyperbolic geometry there must exist certain lines (the asymptotes) which do not change when a hyperbolic rotation is implemented. Therefore, if there exist a particle whose world-line lies on those asymptotes, the direction of the word-line of that particle should not change by a hyperbolic rotation and, hence, its velocity must always be the same for any inertial frame of reference. The experimental fact that the speed of light is the same in any inertial frame provides, therefore, a strong argument in favor of the hyperbolic nature of space-time.

For future use, we shall make some definitions and conventions which will be used throughout the text. Since we intend to deal with particles "moving" in any direction of space-time, it is convenient to employ a metric which is always real and non-negative. Let we define, therefore, the metric by the expression

$$
d s=\sqrt{\left|c^{2} d t^{2}-d x^{2}-d y^{2}-d z^{2}\right|} .
$$

The choice of the metric, of course, does not affect the final results of the theory, since we always have a certain freedom in defining it.

In terms of the metric (11), we can classify the events as time-like, light-like and space-like as the quantity

\footnotetext{
${ }^{2}$ In the case of $|v|>c$ we should consider a extended hyperbolic rotation as discussed in the section 4
} 
$c^{2} d t^{2}-d x^{2}-d y^{2}-d z^{2}$ be positive, zero or negative, respectively. A similar classification can be attributed to particles and frames of reference. Thus, for instance, slower than light particles (bradyons) will be classified as time-like particles and faster than light particles (tachyons) as space-like particles. Particles moving with the speed of light (luxons) will be classified, of course, as light-like particles.

We can also classify the particles according to their "direction of movement" in time. A particle which moves to the future will be called a forward particle and a particle moving to the past, backward particle. A particle with has an infinite velocity exists only in the very present instant and we might call it a momentary particle. A similar classification can be employed for reference frames as well.

\section{The switching principle and an- tiparticles}

In the previous section we have introduced the concept of backward particles as particles which travel back in time. Now we shall clarify how we can interpret them from a physical point of view. However, for the discussion becomes simpler we shall concern ourselves just with time-like particles.

Let us begin by analyzing what must be the energy of a backward particle. We know from the usual theory of relativity that the energy of a (time-like) particle is related to its mass and its momentum through the expression $E^{2}=p^{2} c^{2}+m^{2} c^{4}$. This quadratic expression for the energy has two solutions: one of them represents the positive root of that equation and the other the negative root (geometrically, this equation describes, for a given $m$, the surface of a two-sheet hyperboloid). In the theory of relativity we usually interpret the states of positive energy as states which are accessible to any forward particle or, which is the same, that a forward particle always has a positive energy. Because of this association, we must for consistency regard negative states of energy as accessible only to backward particles, so that any backward particle has a negative energy.

These two separate concepts which not have a physical sense by themselves - namely, particles traveling backward in time and negative states of energy (associated to free particles) - can be reconciled through what is called the switching principle3. This principle is based on the fact that any observer regard the time as flowing from the past to the future and that any measurement of the energy (associated to a free particle) results in a positive quantity. Thus, the switching principle states that a backward particle (whose energy is negative) should always be physically observed as a typical forward particle (whose energy is positive).

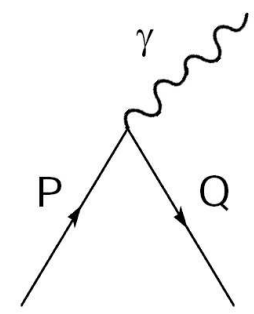

Figure 1: A forward particle $P$ interacts with a photon $\gamma$ and becomes a backward particle $Q$.

Therefore, one might think that there are no differences at all between forward and backward particles, since apparently the latter are always seen in the same way as the first ones. However, this is not so because whenever a backward particle is observed as a forward particle, some of its properties turns out to be switched in the process of observation. For instance, if a backward particle has a positive electric charge, say $+e$, then, due to the conservation of electric charge principle, we must actually observe a "switched" particle carrying the negative charge $-e$. Let us clarify this point through the following experiment.

Consider the phenomenon described in the Figure 1. which describes a forward particle $P$ with electric charge $+e$ who interact at some time with a photon $\gamma$ and, by virtue of this interaction, becomes a backward particle, $Q$. Note that the particle $Q$ actually is the same particle $P$, but now it is traveling back in time. Therefore, the actual electric charge of $Q$ is still $+e$. Nevertheless, when this process is physically observed, the observer should use (even unconsciously) the switching principle and the phenomenon is to be interpreted as follows: two particles of equal mass approach each to the other and, at some point, collide

\footnotetext{
${ }^{3}$ Sometimes the terminology "reinterpretation principle" is employed
} 
and annihilate themselves, which gives rise to a photon. Since the photon has no electric charge and the observed charge of the forward particle is $+e$ it follows that the observed charge of the backward particle has to be $-e$. The conclusion which follows from this is that the sign of the electric charge of a backward particle must be reversed in the process of observation.

Thus, a backward particle of mass $m$ and electric charge $+e$ should always be observed as a forward particle with the same mass and opposite electric charge. But these properties are precisely the same as expected to antiparticles. Therefore the switching principle enable us to interpret a backward particle as an antiparticle. The concept of antiparticles can be seen, hence, as a purely relativistic concept: it is not necessary to talk about quantum mechanics to introduce the concept of antiparticles 4 .

Finally, let us remark that these arguments are also valid in the case of space-like particles, i.e., in the case of tachyons. In the section 8 we shall see that the energy of a tachyon is related to its momentum and mass through the relation $E^{2}=p^{2} c^{2}-m^{2} c^{4}$, an equation which describes now a single-sheet hyperboloid. From this we can see that tachyons must have an interesting property: they can change its status of a forward particle to the status of a backward one (and vice-versa) through a simple continuous motion. In other words, by accelerating a tachyon we can make it turn into an antitachyon and vice-versa (notice moreover that at some moment the tachyon must becomes a momentary particle, i.e., an particle with infinity velocity). This, of course, it is only possible to space-like particles.

\section{Deduction of the extended Lorentz transformations (in two dimensions)}

Let us show now how the Lorentz transformations can be generalized, or extended, to frames of reference moving with a velocity greater than that of light (as well as to frames of reference which travel back in time). In this section we shall discuss however the theory only in two dimensions. As commented before, we meet with several difficulties to formulating a theory of tachyons

\footnotetext{
${ }^{4}$ The connection between backward particles and antiparticles was, of course, proposed already by several scientists (e.g., Dirac [7, Stückelberg [8], Feynman [10, 11], Sudarshan [12], Recami 4] etc.).
}

in four dimensions (these difficulties will be discussed in section 10). We shall give here two deductions for the Extended Lorentz Transformations (ELT), a algebraic deduction and a geometric one.

Algebraic Deduction: since in two dimensions the postulates presented on the previous sections are sufficient to proof that light propagates at the same speed $c$ for any inertial frame, we can take this result as our starting point.

So, consider a certain event whose coordinates are $(c t, x)$ with respect to an inertial frame $R$ and $\left(c t^{\prime}, x^{\prime}\right)$ with respect to another inertial frame $R^{\prime}$ (which moves with the velocity $v$ with respect to $R$ ). Suppose further that the coordinate axes of these frames are always likely oriented and that the origin of $R$ and $R^{\prime}$ coincide when $t^{\prime}=t=05$.

Under these conditions, if a ray of light is emitted from the origin of these frames at $t=0$, then this ray will propagates with respect to $R$ according to the equation

$$
x^{2}-c^{2} t^{2}=0
$$

and for $R^{\prime}$, by the principle of invariance of the speed of light, also by

$$
x^{\prime 2}-c^{2} t^{\prime 2}=0
$$

(2) and (3) implies therefore,

$$
x^{\prime 2}-c^{2} t^{\prime 2}=\lambda(v)\left(x^{2}-c^{2} t^{2}\right),
$$

where $\lambda(v)$ does not depend on the coordinates and the time, but may depend on $v$.

In the other hand, since the frame $R$ moves with respect to $R^{\prime}$ with the velocity $-v$, follows also that

$$
x^{2}-c^{2} t^{2}=\lambda(-v)\left(x^{\prime 2}-c^{2} t^{\prime 2}\right) \text {. }
$$

Therefore, from (4) and (5), we get $\lambda(v) \lambda(-v)=1$. Besides, the hypothesis of homogeneity and isotropy of space-time demands that $\lambda(v)$ does not depend on the velocity direction 6 and then we are led to the condition

$$
\lambda(v)^{2}=1 \quad \Rightarrow \quad \lambda(v)= \pm 1 .
$$

\footnotetext{
${ }^{5}$ Hereafter, whenever we speak in the frames of reference $R$ and $R^{\prime}$ should be implicitly assumed that the relative velocity between them is $v$ and that the conditions above are always satisfied.

${ }^{6}$ Indeed, only in this case the transformations do form a group, see [5].
} 
Thus we have two cases to work on. Let us first analyze the first case, namely, $\lambda(v)=+1$. In this case the equation (4) becomes

$$
x^{\prime 2}-c^{2} t^{\prime 2}=x^{2}-c^{2} t^{2},
$$

whose solution, as it is known, is given by the usual Lorentz transformations,

$$
c t^{\prime}=\frac{c t-x v / c}{\sqrt{1-v^{2} / c^{2}}}, \quad x^{\prime}=\frac{x-v t}{\sqrt{1-v^{2} / c^{2}}} .
$$

Note that these transformations contains the identity (for $v=0$ ) and they are discontinuous only at $v= \pm c$. Consequently, these transformations must be valid on the range $-v<c<v$ as well, but nothing can be said for $v$ out from this range.

In this way, we hope that in the other case, i.e., when $\lambda(v)=-1$, the respective transformations should be related to velocities greater than that of light. Now we will show that this is indeed what happens.

To $\lambda(v)=-1$, equation (4) becomes

$$
x^{2}-c^{2} t^{\prime 2}=-\left(x^{2}-c^{2} t^{2}\right),
$$

Through the formal substitutions $x \rightarrow \pm i \xi$ and $c t \rightarrow$ $\pm i c \tau$, we can rewrite (9) as

$$
x^{\prime 2}-c^{2} t^{\prime 2}=\xi^{2}-c^{2} \tau^{2} .
$$

Equation (10) has the same form as the equation (7) and therefore has the same solution:

$$
c t^{\prime}=\frac{c \tau-\xi v / c}{\sqrt{1-v^{2} / c^{2}}}, \quad x^{\prime}=\frac{\xi-v \tau}{\sqrt{1-v^{2} / c^{2}}} .
$$

Expressing them back in terms of $x$ and $t$, we get

$$
c t^{\prime}= \pm \frac{c t-x v / c}{\sqrt{v^{2} / c^{2}-1}}, \quad x^{\prime}= \pm \frac{x-v t}{\sqrt{v^{2} / c^{2}-1}},
$$

and we have just to remove the signals ambiguity on the expressions above. The correct sign, however, depends on the relatively direction of the frames $R$ and $R^{\prime}$ in their "moviment" on the space-time, and can be seen in the Figure (2). In the case of a forward space-like transformation, it is easy to show that the correct sign is the negative one.

Note that these equations, as well as those of the previous case, are discontinuous only for $v= \pm c$. But now they are real only when $|v|>c$. The equations (12) represent thus the Lorentz transformations between two space-like reference frames, that is, the transformations associated to $|v|>c$, where the correct sign depends if the frame $R^{\prime}$ is a forward or backward reference frame with respect to $R$ and can be determined by the Figure 2 .

Geometrical Deduction: from the geometrical point of view, the ELT can be regarded as a (hyperbolic) rotation defined on the curve 7

$$
\left|c^{2} t^{2}-x^{2}\right|=\rho^{2} \text {. }
$$

We can call such a transformation as an extended hyperbolic rotation. Note that (13) represents a set of two orthogonal and equilateral hyperbolæ. The asymptotes

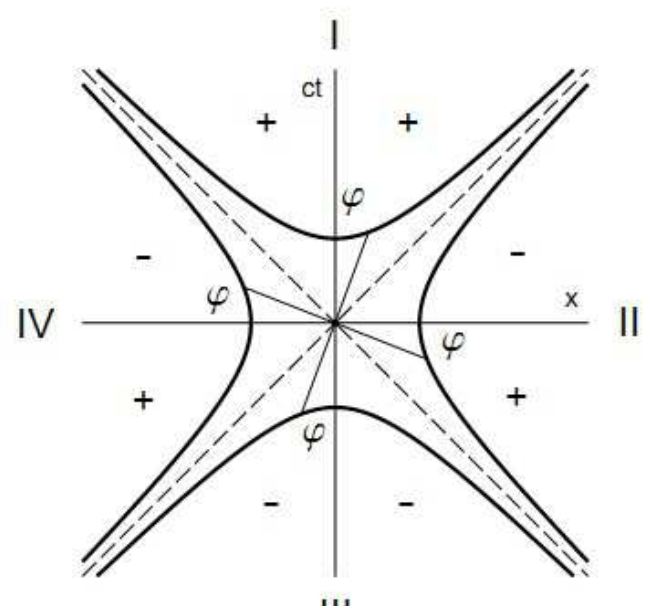

III

Figure 2: The Curve $\left|c^{2} t^{2}-x^{2}\right|=\rho^{2}$.

of this curve divide the plane onto four disjoint regions, namely, the regions I, II, III and IV, as show in the Figure 2 .

To express such a rotation is convenient to introduce the extended hyperbolic functions, $\cosh \theta$ and $\sinh \theta$, de-

\footnotetext{
${ }^{7}$ Such a rotation can be more elegantly described through the concept of hyperbolic-numbers 13. A hyperbolic number is number of the form $z=a+h b$, where $\{a, b\} \in \mathbb{R}$ and $h:\left\{h^{2}=+1, h \notin \mathbb{R}\right\}$. By defining the conjugate $\bar{z}=a-h b$, it follows that $|\overline{z z}|=\left|a^{2}-b^{2}\right|=\rho^{2}$, which represents an equation like (13). This leads to a complete analogy with complex numbers, but with the difference that now these numbers describe a hyperbolic geometry. We also stress that the same can be done through the elegant geometric algebra of space-time [14], with the advantage that this formalism could allow, perhaps, a generalization of these concepts to higher dimensions.
} 
fined by the following relations

$$
c t=\rho \cosh \theta, \quad x=\rho \sinh \theta,
$$

where $\theta$ is the usual circular parameter so that $0 \leq \theta<$ $2 \pi$ and $\rho$ is given by (13). Note that in this geometric description the velocity $v$ is given by

$$
v / c=\tanh \theta .
$$

Expressions for $\cosh \theta$ and $\sinh \theta$ can be determined in several ways. For instance, we can use the usual hyperbolic functions $\cosh \varphi$ and $\sinh \varphi$ (where $\varphi$ is the usual hyperbolic parameter so that $-\infty<\varphi<+\infty$ ) to define them. Effectively, by introducing in each disjoint region of the space-time a hyperbolic parameter $\varphi$, which must be measured as shown in Figure 2, we can see that the functions $\cosh \varphi$ and $\sinh \varphi$ can be used to parametrize each one of the four branches of the curve (13). Once specified the region which $\theta$ belongs, $\rho$ and $\varphi$ determine in a unique way any point of the curve (13) and, therefore, they also determine the extended hyperbolic functions. With these conventions, we find out that

$$
\begin{gathered}
\cosh \theta \equiv \begin{cases}+\cosh \varphi, & \theta \in \mathrm{I} \\
-\sinh \varphi, & \theta \in \mathrm{II} \\
-\cosh \varphi, & \theta \in \mathrm{III} \\
+\sinh \varphi, & \theta \in \mathrm{IV}\end{cases} \\
\sinh \theta \equiv \begin{cases}+\sinh \varphi, & \theta \in \mathrm{I} \\
+\cosh \varphi, & \theta \in \mathrm{II} \\
-\sinh \varphi, & \theta \in \mathrm{III} \\
-\cosh \varphi, & \theta \in \mathrm{IV}\end{cases}
\end{gathered}
$$

where the parameters $\theta$ and $\varphi$ should be related by the formula

$$
\tan \theta=\tanh \theta \equiv\left\{\begin{array}{ll}
+\tanh \varphi, & \theta \in(\mathrm{I}, \mathrm{III}) \\
-\operatorname{coth} \varphi, & \theta \in(\mathrm{II}, \mathrm{IV})
\end{array} .\right.
$$

Expressions for the extended hyperbolic functions can also be found without making use of the usual hyperbolic functions. To do this, we parametrize (13) through the circular functions instead, putting $c t=$ $r \cos \theta$ and $x=r \sin \theta$, with $r=\sqrt{c^{2} t^{2}+x^{2}}$. This allows us to write directly,

$$
\cosh \theta=\frac{\cos \theta}{\sqrt{|\cos 2 \theta|}}, \quad \sinh \theta=\frac{\sin \theta}{\sqrt{|\cos 2 \theta|}} .
$$

or, in terms of the tangent,

$$
\cosh \theta=\frac{\sigma(\theta)}{\sqrt{\left|1-\tan ^{2} \theta\right|}}, \quad \sinh \theta=\frac{\sigma(\theta) \tan \theta}{\sqrt{\left|1-\tan ^{2} \theta\right|}}
$$

where

$$
\sigma(\theta)=\left\{\begin{array}{ll}
+1, & -\pi / 2<\theta<\pi / 2 \\
-1, & \pi / 2<\theta<3 \pi / 2
\end{array} .\right.
$$

The equivalence between (16) and (18) or (19) is found when one takes into account (17).

Once defined the extended hyperbolic functions it is easy to obtain expressions describing an extended hy-

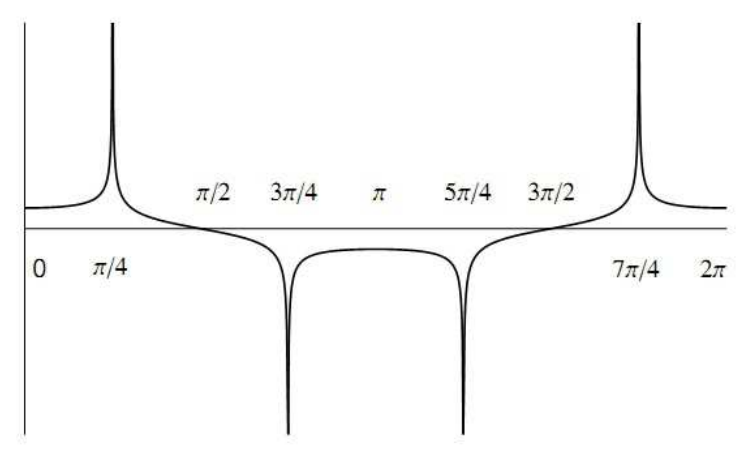

Figure 3: Graphic for the hyperbolic extended function $\cosh \theta$. The graphic of $\sinh \theta$ is similar to this, but with a phase difference of $\pi / 2 \mathrm{rad}$.

perbolic rotation. Let $(c t, x)=\left(\rho \cosh \theta_{1}, \rho \sinh \theta_{1}\right)$ be the coordinates of a point on the plane with respect to a inertial coordinate system $R$, which it is assumed to belongs to the sector I of space-time. If we take a passive hyperbolic rotation (i.e., if we rotate the coordinate axes), say by an angle $\theta_{12}$, we shall obtain a new inertial coordinate system $R^{\prime}$ and the coordinates of that same point become $\left(c t^{\prime}, x^{\prime}\right)=\left(\rho \cosh \theta_{2}, \rho \sinh \theta_{2}\right)$ with respect to $R^{\prime}$. Since $\theta_{12}=\theta_{1}-\theta_{2}$, it follows that

$$
c t^{\prime}=\rho \cosh \left(\theta_{1}-\theta_{12}\right), \quad x^{\prime}=\rho \sinh \left(\theta_{1}-\theta_{12}\right) .
$$

By replacing the expressions of $\cosh \left(\theta_{1}-\theta_{12}\right)$ and $\sinh \left(\theta_{1}-\theta_{12}\right)$ by any one of the above expressions and by simplifying the resulting expressions, taking also into account (17), we find out that $\left(c t^{\prime}, x^{\prime}\right)$ is related to 
$(c t, x)$ through the equations

$$
\begin{aligned}
& c t^{\prime}=\delta\left(\theta_{12}\right)\left(c t \cosh \theta_{12}-x \sinh \theta_{12}\right), \\
& x^{\prime}=\delta\left(\theta_{12}\right)\left(x \cosh \theta_{12}-c t \sinh \theta_{12}\right),
\end{aligned}
$$

where

$$
\delta(\theta)= \begin{cases}+1, & \tan ^{2} \theta<1 \\ -1, & \tan ^{2} \theta>1\end{cases}
$$

Finally, using (19) and putting $\tan \theta_{12}=v / c$, we obtain directly the required transformations, which are identical to those obtained before, namely,

$$
c t^{\prime}=\varepsilon\left(\theta_{12}\right) \frac{c t-x v / c}{\sqrt{\left|1-v^{2} / c^{2}\right|}}, \quad x^{\prime}=\varepsilon\left(\theta_{12}\right) \frac{x-v t}{\sqrt{\left|1-v^{2} / c^{2}\right|}}
$$

where we put $\varepsilon\left(\theta_{12}\right)=\sigma\left(\theta_{12}\right) \delta\left(\theta_{12}\right)$. $\varepsilon\left(\theta_{12}\right)$ determines the correct sign which must appear in front of these transformations, as can be visualized in the Figure 2

\section{The composition law of veloc- ities and inverse transforma- tions}

The transformations deduced in the previous sections do form a group. The ordinary Lorentz transformations is just a subgroup of it. Let us demonstrate now this group structure.

First, note that the identity is obtained with $v=0$. We shall show now that the composition of two ELT still results in another ELT. For this we introduce a third inertial frame $R^{\prime \prime}$, which moves with respect to $R^{\prime}$ with velocity $u=c \tanh \theta_{23} . R^{\prime}$ by its turn is assumed to moves with the velocity $u=c \tanh \theta_{12}$ with respect to $R$. We already know the transformation law between $R$ and $R^{\prime}$, and we can write it down:

$$
\begin{aligned}
& c t^{\prime}=\varepsilon\left(\theta_{12}\right) \frac{c t-x \tanh \theta_{12}}{\sqrt{\left|1-\tanh ^{2} \theta_{12}\right|}} \\
& x^{\prime}=\varepsilon\left(\theta_{12}\right) \frac{x-c t \tanh \theta_{12}}{\sqrt{\left|1-\tanh ^{2} \theta_{12}\right|}}
\end{aligned}
$$

In its turn, the law of transformation from $R^{\prime}$ to $R^{\prime \prime}$ is given by an analogous expression:

$$
\begin{aligned}
& c t^{\prime \prime}=\varepsilon^{\prime}\left(\theta_{23}\right) \frac{c t^{\prime}-x^{\prime} \tanh \theta_{23}}{\sqrt{\left|1-\tanh ^{2} \theta_{23}\right|}}, \\
& x^{\prime \prime}=\varepsilon^{\prime}\left(\theta_{23}\right) \frac{x^{\prime}-c t^{\prime} \tanh \theta_{23}}{\sqrt{\left|1-\tanh ^{2} \theta_{23}\right|}} .
\end{aligned}
$$

In these equations $\varepsilon^{\prime}\left(\theta_{23}\right)$ determines the signals corresponding to the transformation from $R^{\prime}$ to $R^{\prime \prime}$. These signals, however, do not need to equal necessarily the signals related to the transformation from $R$ to $R^{\prime}$. Indeed, while in the definition of $\varepsilon\left(\theta_{12}\right)$ the frame of reference $R$ was supposed to belong to the region I of space-time, the frame $R^{\prime}$ might belong to any region of space-time. Thus, $\varepsilon^{\prime}\left(\theta_{23}\right)$ should be regarded as a function to be yet determined.

Substitution of (25) into (26) gives us the law of transformation between $R$ and $R^{\prime \prime}$. After some simplifications, one can verify that the resulting expressions have the same form of the ELT, namely

$$
\begin{aligned}
& c t^{\prime \prime}=\varepsilon^{\prime \prime}\left(\theta_{13}\right) \frac{c t-x \tanh \left(\theta_{13}\right)}{\sqrt{\left|1-\tanh ^{2}\left(\theta_{13}\right)\right|}} \\
& x^{\prime \prime}=\varepsilon^{\prime \prime}\left(\theta_{13}\right) \frac{x-c t \tanh \left(\theta_{13}\right)}{\sqrt{\left|1-\tanh ^{2}\left(\theta_{13}\right)\right|}} .
\end{aligned}
$$

where

$$
\varepsilon^{\prime \prime}\left(\theta_{13}\right)=\frac{\varepsilon\left(\theta_{12}\right) \varepsilon^{\prime}\left(\theta_{23}\right)}{\delta\left(\theta_{12}, \theta_{23}\right)}
$$

with

$$
\delta\left(\theta_{12}, \theta_{23}\right)=\left\{\begin{array}{ll}
+1, & \tanh \theta_{12} \tanh \theta_{23}<1 \\
-1, & \tanh \theta_{12} \tanh \theta_{23}>1
\end{array},\right.
$$

and

$$
\tanh \left(\theta_{13}\right)=\frac{\tanh \theta_{12}+\tanh \theta_{23}}{1+\tanh \theta_{12} \tanh \theta_{23}}=\tanh \left(\theta_{12}+\theta_{23}\right) .
$$

From (17) we can see that (30) consists of a generalization of the addition formula for the hyperbolic tangent, which reveals its geometric meaning. In terms of the velocity $v$, equation (30) can be rewritten as

$$
w=\frac{u+v}{1+u v / c^{2}} .
$$


Equation (31) expresses the composition law of velocities in this extended theory of relativity. It is exactly the same as predicted by the usual theory of relativity, but now it applies to any value of velocity.

Let we show also that the inverse transformation does exist. To do this, we impose onto (27) the conditions $c t^{\prime \prime}=c t$ and $x^{\prime \prime}=x$ and require that the resulting transformation be the identity. For this it is necessary to have $\theta_{23}=-\theta_{12}$ and $\varepsilon^{\prime \prime}\left(\theta_{13}\right)=1$, which enable us to evaluate $\varepsilon^{\prime}\left(\theta_{23}\right)$ from the resulting expression of $\varepsilon^{\prime \prime}\left(\theta_{13}\right)$. In fact, we find that

$$
\varepsilon^{\prime}\left(\theta_{23}\right)=\delta\left(\theta_{12}\right) / \varepsilon\left(\theta_{12}\right)=\sigma\left(\theta_{12}\right),
$$

since $\delta\left(\theta_{12},-\theta_{12}\right)=\delta\left(\theta_{12}\right)$, with $\delta\left(\theta_{12}\right)$ given (23).

Substituting this result into (26) we obtain the required expressions for the inverse transformations, which when expressed in terms of the velocity $v$ are given by

$$
\begin{aligned}
& c t=\varepsilon^{-1}\left(\theta_{12}\right) \frac{c t^{\prime}+x^{\prime} v / c}{\sqrt{\left|1-v^{2} / c^{2}\right|}} \\
& x=\varepsilon^{-1}\left(\theta_{12}\right) \frac{x^{\prime}+v t^{\prime}}{\sqrt{\left|1-v^{2} / c^{2}\right|}}
\end{aligned}
$$

and where we put $\varepsilon^{-1}\left(\theta_{12}\right)=\sigma\left(\theta_{12}\right)$.

Note that the signs appearing on the inverse transformation are different from that present on the direct transformations. This difference is a consequence of what was commented before, that in the transformation from $R$ to $R^{\prime}$ we had assumed the starting frame $R$ always belonging to the region I of space-time, while in the transformation from $R^{\prime}$ to $R$ it is the frame $R^{\prime}$ which is fixed on the region I. When $|v|<c$ this asymmetry has no effect at all, since in this case the signals are always the same in both expressions. But when $|v|>c$ however, we should alert that the inverse transformations can not be simply obtained by replacing $v$ by $-v$. It is still necessary multiply them by -1 .

Finally, we mention that the associativity of ELT can be shown in a similar way, which completes the group structure of the ELT.

\section{Conjugate Frames of Reference}

We shall introduce now an important concept which can only be contemplated in an extended theory of relativity: the concept of conjugate frames of reference.
The definition is the following: two frames of reference are said to be conjugate if their relative velocity is infinite. Thus, if $v$ is the velocity of the frame $R^{\prime}$ with respect to the frame $R$, the conjugate frame of reference associated to $R^{\prime}$ is another reference frame $R^{*}$, whose velocity is $w=c^{2} / v$ when measured by $R$. In fact, we obtain from (31),

$$
\lim _{u \rightarrow \infty}\left(\frac{u+v}{1+u v / c^{2}}\right)=\frac{c^{2}}{v} .
$$

Conjugate frames of reference are important because a space-like Lorentz transformation between two frames, say, from $R$ to $R^{\prime}$, can be obtained also by a usual Lorentz transformation between $R$ and $R^{*}$. For this, we simply have to replace $v \rightleftharpoons c^{2} / 2, c t^{*} \rightleftharpoons x$ and $x^{*} \rightleftharpoons c t$. In fact, since $w=c^{2} / v$ is less than $c$ for $v>c$, it follows that the transformation from $R$ to $R^{*}$ is given by

$$
c t^{*}=\frac{c t-x w / c}{\sqrt{1-w^{2} / c^{2}}}, \quad x^{*}=\frac{x-w t}{\sqrt{1-w^{2} / c^{2}}} .
$$

Making the replacements indicated above we can see in this way that we shall get the correct transformations between $R$ and $R^{\prime}$.

From a geometrical point of view the passage of a given frame of reference to its conjugate consists of a reflection of the coordinate axes relatively to the asymptotes of the curve (13), since this reflection precisely has the the effect of changing $c t$ by $x$ and vice-versa (and thus the effect of replacing $v$ by $c^{2} / v$ ). Therefore, we can see that an extended Lorentz transformation can be reduced to a usual Lorentz transformation by performing appropriate reflections relatively to asymptotes (in case of a space-like transformation) and around the origin (for a backward time-like transformation). This gives us a new way to derive the ELT.

It is interesting to notice also that, if a particle has velocity $u=c^{2} / v$ with respect to the frame $R$, then the velocity of this particle for the frame $R^{\prime}$ will be infinite. In other words this particle becomes a momentary particle to the frame $R^{\prime}$. More important than that, if the particle velocity $u$ is greater than $c^{2} / v$, and $v<c$, this particle becomes a backward particle to $R^{\prime}$ and it should be observed as an antiparticle by this reference frame. On the other hand, if $v>c$ the frame of reference $R^{\prime}$ should observe an antiparticle whenever $u<c^{2} / v$.

In an analogous way, since the frame $R^{\prime}$ moves with the velocity $-v$ with respect to $R$, it follows also that 
a particle with velocity $u^{\prime}=c^{2} / v$ must have an infinite velocity with respect to $R$. So, in the case of $|v|<c$, the reference frame $R$ should observe an antiparticle if $u^{\prime}<c^{2} / v$ and, in the case of $|v|>c$, only if $u^{\prime}>-c^{2} / v$. These relationships might be, of course, more easily found by analyzing (30) or (31).

\section{$7 \quad$ Rulers and clocks}

Consider two identical clocks, one of them fixed in the frame $R$ and the other fixed to the frame $R^{\prime}$. Further, consider that these clocks are synchronized on $t=t^{\prime}=$ 0 , where $R$ and $R^{\prime}$ are in the same position. We wish to compare the timing rate of these clocks, as measured by one of those frames. For example, suppose we want to compare the rhythm of these clocks when the time intervals are always measured by $R$. For this, suppose that the clock fixed on $R^{\prime}$ takes the time $\tau^{\prime}$ to complete a full period of oscillation. The time $T$ corresponding to this period of time, but now measured by $R$, can be found through the inverse transformations (33). Since this clock is at rest with respect to $R^{\prime}$, we should put $x^{\prime}=0$ on the first of the formulæ (33) and we shall get

$$
T=\varepsilon^{-1}(\theta) \frac{\tau^{\prime}}{\sqrt{\left|1-v^{2} / c^{2}\right|}} .
$$

Then, we can verify that a forward moving clock (with respect to $R$ ) becomes slower in measuring time than an identical clock at rest, when the speed of the clock is less than that of light (as it is well-known). But for a faster than light clock we get that it continues to be slower for $|v / c|<\sqrt{2}$ and it becomes faster when $|v / c|>\sqrt{2}$. It is interesting to note that for $|v / c|=\sqrt{2}$ both clocks go back to work at the same timing rate. Moreover, in the case of a backward moving clock, we can see from the switching principle that this clock should work in the counterclockwise, which is due to the fact that a backward-clock should mark the time from the future to the past.

Let us now verify what we got when the clocks are appreciated by the reference frame $R^{\prime}$. In this case we should use the direct transformations and thus we shall get

$$
T^{\prime}=\varepsilon(\theta) \frac{\tau}{\sqrt{\left|1-v^{2} / c^{2}\right|}},
$$

where $\tau$ is the time spent by the clock fixed at $R$ (which is moving with speed $-v$ with respect to $R^{\prime}$ ) for it to complete a full oscillation. Now, the signal appearing on (37) is determined according to the Figure 2 and the analysis becomes more or less complicated. Of course, we have no problems at all when $|v|<c$, then we shall analyze only the case where $|v|>c$. Suppose first that the reference frame $R^{\prime}$ is a forward frame with respect to $R$. In this case we find that $\varepsilon(\theta)=-1$ and the moving clock will work in the opposite direction as compared to the clock fixed at $R^{\prime}$. This means that the clock at $R$ is a backward-clock with respect to $R^{\prime}$. We can convince ourselves of this from what was commented in the previous section, where it is necessary to put there $u=0$ and $|v|>c$ (and therefore $u<c^{2} / v$ ).

This is an interesting situation indeed, because we have just seen that for the frame $R$, both clocks work clockwise (if the clocks are forward ones) or counterclockwise (if the clocks are backward ones) when $|v|>c$. In the other hand, for the frame $R^{\prime}$ if its own clock is working clockwise, then the moving clock should work counterclockwise and vice-versa. In the case where the reference frame $R^{\prime}$ is backward with respect to $R$ these asymmetries persists yet, but now is the frame $R$ which will see both clocks working differently, while for $R^{\prime}$ they will work accordingly. These asymmetries, of course, just express the fact that the extended Lorentz transformations, the direct and inverse one, are asymmetric by themselves in the case of $|v|>c$.

Let we consider now two identical rulers, one of them placed at rest in the frame $R$ and the other placed at rest with respect to $R^{\prime}$. We wish to compare the length of these rulers, when analyzed by one of these frames. If $l_{0}^{\prime}$ is the length of the ruler at $R^{\prime}$, when measured by this frame, the respective length $L$, as measured by $R$, is obtained by determining where the extreme points of the moving ruler is at a given instant $t$, say, $t=0$. Making use of the second equation of the direct transformations, we find that

$$
L=\varepsilon(\theta) \cdot l_{0}^{\prime} \sqrt{\left|1-v^{2} / c^{2}\right|},
$$

To $|v|<c$ we have the usual Lorentz contraction, but for $|v|>c$ we get that the moving ruler will be smaller than the ruler at rest when $|v / c|<\sqrt{2}$. The rulers go back once again to have the same length when $|v / c|=\sqrt{2}$ and, finally, for $|v / c|>\sqrt{2}$ they should present a "Lorentz dilatation." Moreover, regarding $R^{\prime}$ as a forward frame with respect to $R$, it follows that for the frame $R$ the moving ruler will be oriented contrarily with respect to the ruler at rest. 
If, on the other hand, measurements are made by $R^{\prime}$, then we find that

$$
L^{\prime}=\varepsilon^{-1}(\theta) \cdot l_{0} \sqrt{\left|1-v^{2} / c^{2}\right|},
$$

and now for the reference frame $R$ the ruler at motion (which has the velocity $-v$ ) point out to the same direction as its ruler at rest. We find again the same asymmetry commented above for the clocks. These results can, of course, be more easily obtained - and fully understood - through Minkowski diagrams.

\section{Dynamics}

In this section we intend to answer some questions concerning the dynamics of tachyons. The expressions for the energy and momentum for a faster than light particle will be deducted and we shall show how these particles behave in the presence of a force field.

As a starting point we might assume that the principle of stationary action also applies to faster than light particles. This, of course, follows directly from the assumption of homogeneity and isotropy of space-time, since we know that this principle is true for slower than light for particles.

As one knows, the principle of stationary action states that there exist a quantity $S$, called action, which assumes an extreme value (maximum or minimum) for any possible movement of a mechanical system (in our case, a particle). On the other hand, in the absence of forces, the motion of a particle corresponds to a space-time geodesic, which reduces to a straight line by neglecting gravity. This means that in case of a free particle the differential of action $d S$ should be proportional to the line element $d s$ of the particle and we can write in this way

$$
d S=\alpha d s, \quad d s=\sqrt{\left|c^{2} d t^{2}-d x^{2}-d y^{2}-d z^{2}\right|} .
$$

We must emphasize, however, that the constant of proportionality $\alpha$ can take different values at different regions of space-time, since these regions are completely disconnected regions. Therefore, it is convenient to consider each case separately.

In the case of a forward and time-like particle, (40) takes the form

$$
d S=\mathcal{L}(u) d t, \quad \mathcal{L}(u)=\alpha c \sqrt{1-u^{2} / c^{2}},
$$

where we had introduced the LaGrange function, $\mathcal{L}(u)$, to express the action in terms of particle velocity.
As it is known, the expressions for the energy and momentum are obtained by the formulas

$$
p(u)=\frac{\partial \mathcal{L}(u)}{\partial u}, \quad E(u)=u\left[\frac{\partial \mathcal{L}(u)}{\partial u}\right]-\mathcal{L}(u) .
$$

Applying (42) onto (41) we obtain, thus

$$
p(u)=-\frac{\alpha u / c}{\sqrt{1-u^{2} / c^{2}}}, \quad E(u)=-\frac{\alpha c}{\sqrt{1-u^{2} / c^{2}}} .
$$

To find $\alpha$ we may use the fact that for low speeds these expressions should reduce to that obtained by Newtonian mechanics. Thus, for instance, if we expand the expression for the momentum in a power series of $u / c$ and we keep only the first term, we should get $p \approx-\alpha u / c$, while Newtonian mechanics provides $p=m u$. Thus we get $\alpha=-m c$ and then

$$
p(u)=\frac{m u}{\sqrt{1-u^{2} / c^{2}}}, \quad E(u)=\frac{m c^{2}}{\sqrt{1-u^{2} / c^{2}}},
$$

which are the same expressions of the usual theory of relativity.

In the case of a forward space-like particle (i.e. in the case of a forward tachyon), the LaGrange function takes the form

$$
\mathcal{L}(u)=\alpha c \sqrt{u^{2} / c^{2}-1}
$$

and we get by (42), the following expressions for momentum and energy,

$$
p(u)=\frac{\alpha u / c}{\sqrt{u^{2} / c^{2}-1}}, \quad E(u)=\frac{\alpha c}{\sqrt{u^{2} / c^{2}-1}} .
$$

The constant $\alpha$, however, no longer can be determined by comparing these expressions with those obtained in Newtonian mechanics, since the velocity of the particle is always greater than the speed of light in this case. But we can stead evaluate the limit of these expressions as $u \rightarrow \infty$, which give us

$$
\lim _{u \rightarrow \infty} p(u)=\alpha, \quad \lim _{u \rightarrow \infty} E(u)=0,
$$

by where we can see that $\alpha$ equals the momentum of a momentary particle, that is, the momentum of a infinitely fast particle.

Since the mass of a particle must be a universal invariant, it follows that we can also define a metric in 

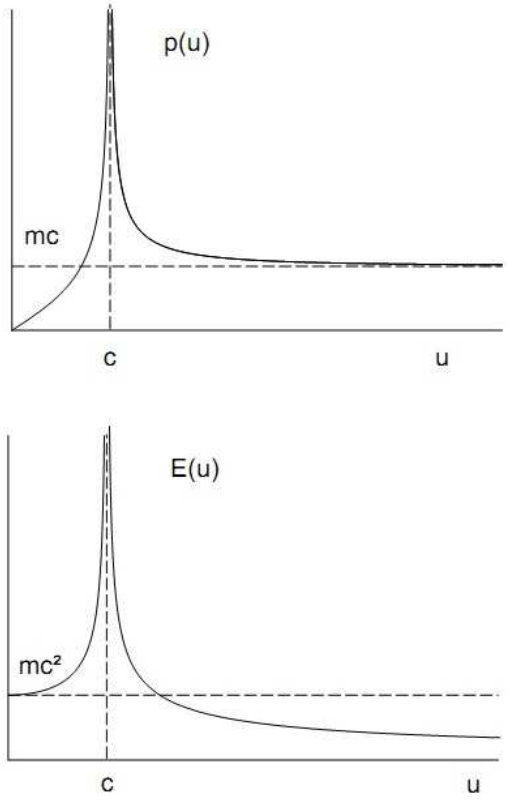

Figure 4: Graphics for the momentum and energy of a forward particle with speed $0 \leq u<\infty$.

the space of energy and momenta. Making an analogy with (1), we can define this dynamic metric as

$$
c^{2} d m=\sqrt{\left|d E^{2}-c^{2} d p_{x}^{2}-c^{2} d p_{y}^{2}-c^{2} d p_{z}^{2}\right|} .
$$

Thus, it follows that the mass, the energy and the momentum must always be related by the formula $m c^{2}=\sqrt{\left|E^{2}-c^{2} p^{2}\right|}$. If we put $E=0$ in this last equation, we get $p=m c$ (we had assumed that $p$ is positive for $u$ positive). We conclude in this way that the momentum and energy of a tachyon should be given by the expressions

$$
p(u)=\frac{m u}{\sqrt{u^{2} / c^{2}-1}}, \quad E(u)=\frac{m c^{2}}{\sqrt{u^{2} / c^{2}-1}} .
$$

This result can also be obtained through the use of conjugate frames, introduced in section 6. Suppose a particle with velocity $u>c$ with respect to a reference frame $R$. Then, for the conjugate reference frame $R^{*}$ this particle will have energy $E^{*}=c p$ and momentum $p^{*}=E / c$, while its velocity becomes $w=c^{2} / u$, which is less than $c$. But the expressions for momentum and energy of a bradyon (i.e., a time-like particle) are given by (42) and we get, therefore

$$
p^{*}=\frac{m w}{\sqrt{1-w^{2} / c^{2}}}, \quad E^{*}=\frac{m c^{2}}{\sqrt{1-w^{2} / c^{2}}} .
$$

We can verify in this way that the replacements of $E^{*}$, $p^{*}$ and $w$ into the above formulæ result exactly in the expression (49).

In the case of backward particles, the LaGrange function changes sign, since $d t$ is negative and $\mathcal{L}=d S / d t$. Therefore, backward particles must have a negative energy, a result which we had already indicated in section 3.

Finally, let us show how a space-like particle should behave when subjected to a force field. The expression for the force acting on the particle remains, of course, being given by Newton's Law $\dot{p}=F$, but now $p$ is given by (49). Calculating the derivative, we obtain

$$
F=-\frac{m a}{\left(u^{2} / c^{2}-1\right)^{3 / 2}},
$$

where the $a=d u / d t$ denotes the acceleration of the particle. Note that the force and the acceleration point out to opposite directions. Consequently, two space-like particles that attract (repel) must go far (go near) one from the other. The concepts of attraction/approximation and repulsion/expulsion, therefore, are no longer equivalent concepts when we deal with tachyons. In fact, if we try to approach (move away) from a tachyon, its relative speed decrease (increase), an effect that is contrary to our common sense but that can be demonstrated by a simple analysis of (31).

\section{Causality and the Tolman Paradox}

One of the arguments usually employed to show that faster than light particles can not exist is that their existence would imply a violation of the principle of causality. Indeed, suppose a tachyon is emitted by a body $A$ at time $t_{A}$ and it is absorbed by another body $B$ at time $t_{B}$, where $t_{B}>t_{A}$. Since these two events (emission of a tachyon by $A$ and its absorption by $B$ ) are separated by a space-like distance we know from the theory of relativity that it is possible to find a determined frame of reference (whose speed is less than 
that of light) where the chronological order of events is reversed. Thus, if we assume the event $A$ as the cause of the event $B$, we shall conclude then, for this moving frame of reference, that the effect precedes its cause.

Therefore, if we admit the concepts of cause and effect as absolute concepts and that the cause always precedes the effect, we would then effectively be led to the conclusion that faster than light particles can not exist. However, there is nothing from the mathematical point of view that supports this hypothesis. On the contrary, if we assume a complete isotropy and homogeneity of space-time, we have no choice but to consider the concepts of cause and effect as relative concepts.

We already had seen, of course, other quantities which were regarded as absolute in the usual theory of relativity and now they had to be seen as relative quantities. An example of this is the concept of emission and absorption. Indeed, since by the switching principle we did not observe backward-particles but only forwardantiparticles, the processes of emission (absorption) of backward-particles should always be observed as an absorption (emission) of forward-antiparticles. We can, of course, find out if a particle was actually emitted (absorbed) by analyzing the process in the frame where the source (emitter) is at rest, in this case we shall speak of an intrinsic or proper emission (absorption).

Nevertheless, the relative nature of causality does not lead to any contradiction into the theory. In nature, a phenomenon never describes an isolated event but only a continuous succession of events, which we shall call a physical process. Geometrically, a physical process describes a continuous curve in space-time and therefore has an absolute character: the order in time in which events occur may differ from a reference frame to another but the curve itself, which corresponds to the phenomenon in question, should be the same for any of them. This is enough for instance to show that we can not go back in time and kill our grandfather. In fact, the mere fact of our existence means that there exists a curve in space-time connecting our grandfather to us, and since this curve has an absolute character, it can not be disconnected to any observer, even backing in time.

As an example of a paradox which involves the concept of causality, let us examine the interesting paradox proposed and discussed by Tolman [15] in 1917 (although it had been pointed out ten years earlier by Einstein [16]). Further details can be checked in [17, 18, 19].
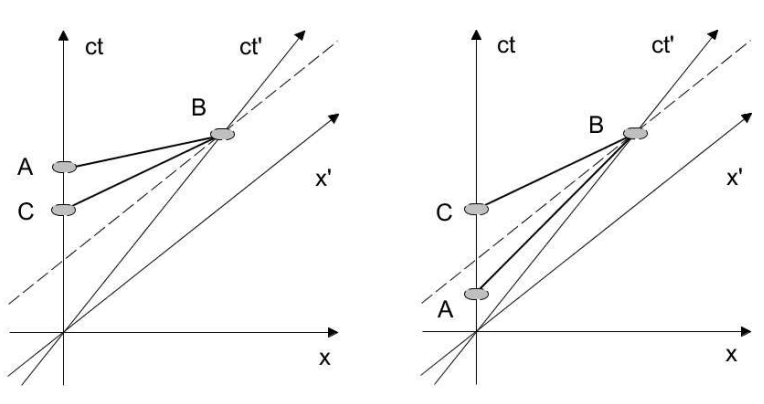

Figure 5: Experiment devised by Tolman.

The paradox consists in showing that if faster than light particles does exist, then it would be possible to send information to the past. To show this, consider the references $R$ and $R^{\prime}$ (with $R^{\prime}$ moving with speed $v<c$ with respect to $R$ ) are equipped with some special phone devices, whose communication is done through the transmission of tachyons. Imagine, then, that an observer $R$ sends a message (event $A$ ), for instance in the form of a question, to $R^{\prime}$ and that after he had received (event $\mathrm{B}), R^{\prime}$ sends back his answer to $R$, which is then received by $R$ (event $C$ ). It turns out that, as seen in Figure 5 , the observer $R^{\prime}$ can calibrate its device in such a way that the message sent by him arrives at $R$ even before $R$ had sent its question. Thus, since $R$ got the answer before he had make the ask, he might decides to not do the question, in which case we shall meet to a very paradoxical situation.

The failure on this argument is that it mixes the descriptions of the reference frames when the terms "emition" and "absorption" are employed. In fact, we shall show now (following 44) that if the frame of reference $R^{\prime}$ intrinsically receives the question submitted by $R$, as well as he intrinsically sends its answer, then the frame of reference $R$ should always receive the reply after he had make the ask.

For this, suppose that the question of $R$ is sent with velocity $u_{1}$ and the answer comes back with the velocity $u_{2}$, where $u_{1}$ and $u_{2}$ are greater than the speed of light and they are always measured by $R$. Notice then that for the answer of $R^{\prime}$ arrives before the question sent by $R$ it is necessary to have $\left|u_{1}\right|>\left|u_{2}\right|$ because for $R$ the event $C$ occurs before $A$ and both arrive on $B$ at the same time. Nevertheless, for the frame of reference $R^{\prime}$ to receive intrinsically the question sent by $R$ 
it is necessary to have $\left|u_{1}\right|<c^{2} / v$, since in the other case, as we have seen in section 6 , this message would be a backward-message to $R^{\prime}$ and hence $R^{\prime}$ would simply see the emission of the message by transmission of antitachyons as predicted by the switching principle. Similarly, for $R^{\prime}$ intrinsically to send its answer, we must have $\left|u_{2}\right|>c^{2} / v$, since the answer is sent in the negative direction of the axis $X$ of $R$. Thus, we had show that $\left|u_{2}\right|>\left|u_{1}\right|$, a contradiction.

Therefore, if the reference $R^{\prime}$ effectively receives the question sent from $R$ and effectively sends her answer, the process must be described by the Figure $5 \mathrm{~b}$, not by the Figure 5a. In this case, the answer always comes after the question sent by $R$.

Of course, the Figure 5 a also represents a valid physical process, but not one as described by the Tolman paradox. Each frame of reference should have its own view of what is actually happening in it. For instance, for $R$ the experiment described by Figure $5 \mathrm{a}$ corresponds to the case where there is, first, the emission of the message $C$ (through an antitachyon jet) and soon after, there is the emission of the message $A$ (via a tachyon jet); finally, both messages come together at $B$. But for $R^{\prime}$ all happens as he had sent the message $C$ to $R$ by an antitachyon jet and, at the same time, sent the message $A$ by means of a tachyons jet; then after some time the observer $R$ would receive the message $C$ and then the message $A$. Note that the chronological order of the events depends on the frame considered, but the process itself (which connects the events $A, B$ and $C$ ) is unique.

\section{Difficulties for formulating the theory of tachyons in four dimensions}

In the section 4 we show that in two dimensions the Lorentz transformations can be extended in order to relate any imaginable pair of inertial frames. When, however, we try to do the same in four dimensions we meet with serious difficulties, which we shall briefly discuss now.

Let us remind the reader that by extending the Lorentz transformations in two dimensions, we had made use of an important principle, which states that the speed of light is the same in any inertial frame. We saw, moreover, that this principle can be deduced from the postulates presented in section 2, and hence this principle can be seen as a theorem of the relativity theory. When, however, we pass to a universe in four dimensions, is no longer possible to proof the general validity of this theorem, in the same way as we did in two dimensions. Actually, in four dimensions we can not even say that light travels in spherical surfaces with speed $c$ in all inertial frame of reference (it is only in the case of $v<c$ we can mathematically proof this assertion, from the postulates of relativity).

To show more clearly why we meet with these difficulties, let us consider for example a source of light fixed on the origin of the frame $R$ and suppose that with respect to this frame light propagates in spherical surfaces with velocity $c$. In four-dimensional spacetime the asymptotes are replaced by a cone - the light cone. The geometric region of space-time associated to a beam of light (emitted by the source fixed at the origin of the reference frame $R$ ) always belongs to this light cone.

The usual theory of relativity also shows that for any other time-like frame of reference, the propagation of light is still represented by the same light cone. But how should the light behave itself with respect to a space-like frame, say, $R^{\prime}$ ? In this case, the time axis of this frame always point out to the outside region of the light cone of $R$, so that is not evident that the light emitted by the source fixed at $R$ should also propagates in spherical surfaces with speed $c$ with respect to $R^{\prime}$. Beside this, we might ask what happens when a light source is fixed on $R^{\prime}$. Does the light emitted by this source propagates in spherical surfaces with speed $c$ with respect to $R^{\prime}$ ? And what is to be said with respect to the frame $R$, where the source has velocity $v>c$, does the light propagates spherical waves with speed $c$ ?

As one can see, there are several issues that can not be answered immediately, not without having additional information. Indeed, the behavior of light depends on its intrinsic properties, and these properties are determined by a extended theory of electromagnetism which is a priori unknown. Let us examine these possibilities a little more.

We can suppose for instance that the source of light fixed at $R^{\prime}$ (which we shall suppose to have a velocity greater than $c$, with respect to $R$ ) also emits spherical waves with speed $c$, when measured by $R^{\prime}$. So, there must exist now another light cone corresponding to space-like frames of reference, a cone which must contour the axis of time of $R^{\prime}$. Since the axis of time of 
$R$ always should be outside from this new light cone, it follows that for $R$ the light emitted by the moving source will not propagates into spherical surfaces of speed $c$, but rather it will take a form of a two-sheet hyperboloid surface. In this case the speed of light would depend of the direction and space-time could no longer be considered isotropic anymore.

If, in other hand, we regard that the light emitted by the source fixed on $R^{\prime}$ also propagates in spherical surfaces with respect to the reference frame $R$, that is, that there are a unique light cone in the universe by where the light always "travels", no matter what is the speed of the source, then we can see that, although for $R$ the light propagates in spheres of speed $c$, now the same is not true for $R^{\prime}$, which should observes the light to propagating in a two-sheet hyperboloid.

For light spread in spherical surfaces and with velocity $c$ to both reference frames is necessary that the transverse coordinates, $y^{\prime}$ and $z^{\prime}$ of the frame $R^{\prime}$ be imaginary quantities (assuming $y$ and $z$ real). Indeed, just in this case we can map a "time-like light cone" to a "space-like light cone." Effectively, this can be shown by deducing the ELT in four dimensions, assuming from the start the validity of the principle of invariance of the speed of light to any inertial frame. We have in this case,

$$
x^{\prime 2}+y^{\prime 2}+z^{\prime 2}-c^{2} t^{\prime 2}=\lambda(v)\left(x^{2}+y^{2}+z^{2}-c^{2} t^{2}\right),
$$

in place of (4). As it is known, the solution of this equation for $\lambda(v)=+1$ consists of the usual Lorentz transformations, while for $\lambda(v)=-1$ we shall get

$$
\begin{gathered}
c t^{\prime}= \pm \frac{c t-x v / c}{\sqrt{v^{2} / c^{2}-1}}, \quad x^{\prime}= \pm \frac{x-v t}{\sqrt{v^{2} / c^{2}-1}} \\
y^{\prime}= \pm i y, \quad z^{\prime}= \pm i z
\end{gathered}
$$

and the transverse coordinates $y^{\prime}$ and $z^{\prime}$ become imaginary. The introduction of imaginary coordinates is, however, deprived of physical sense 8 .

\footnotetext{
${ }^{8}$ Some authors, for instance [20, argue that the introduction of imaginary coordinates in the theory does not constitute a problem. The solution proposed by them consists by regarding the coordinate axis $Y^{\prime}$ and $Z^{\prime}$ themselves as imaginary axes, so that the observers in the (space-like) frame of reference $R^{\prime}$ always should interpret the coordinates $y^{\prime}$ and $z^{\prime}$ as relatively real quantities. This, however, is not consistent. Indeed, let we take for instance a ray of light which propagates on the $Y$ direction with respect ot $R$. For the frame of reference $R^{\prime}$, the light travels through an oblique trajectory, and the components of its veloc-
}

If, by its turn, we deny the validity of the principle of invariance of the speed of light, then we obtain the transformations

$$
\begin{gathered}
c t^{\prime}= \pm \frac{c t-x v / c}{\sqrt{v^{2} / c^{2}-1}}, \quad x^{\prime}= \pm \frac{x-v t}{\sqrt{v^{2} / c^{2}-1}} \\
y^{\prime}= \pm y, \quad z^{\prime}= \pm z
\end{gathered}
$$

where now all coordinates are real. The problem here is that we lie in the cases discussed above, where the space-time can not be considered isotropic.

Note that in each one of the possibilities discussed above, the transverse components of the physical quantities become different. Thus, for example, the formulation of the electrodynamics of tachyons will assume different forms in each one of these formulations. Only the experiment can decides which one or another is the correct, (assuming that someone of them are correct).

In short, the arguments presented above show us that in a four-dimensional universe we can not extend the Lorentz transformations in order to satisfy all the postulates presented in section 2, unless it is introduced imaginary quantities, which has no physical interpretation. We shall see in the next section that, if we not impose the validity of the postulate 1 , i.e. that the universe is four-dimensional, then it becomes possible to build up a theory of tachyons which satisfy the other postulates fully.

\section{An possible theory in six di- mensions}

We might wonder why we find difficulties on extending the Lorentz transformations in a four-dimensional universe if in a two-dimensional universe this generalization is straightforward. We can figure out what is happening by reflecting a little about. The reason by which this occurs lies in the fact that in four dimensions the number of space-like dimensions is different from the number of time-like dimensions (3 space-like dimensions against 1 time-like dimension). Since experience shows us that the universe has three space-like dimensions (at least), it follows that we must consider

ity will have the magnitudes $\left|c_{x}^{\prime}\right|=v$ and $\left|c_{y}^{\prime}\right|=c \sqrt{v^{2} / c^{2}-1}$. Thus, for the ray of light to propagate with speed $c^{\prime}=c$, it is necessary that the square of $c_{y}^{\prime}$ be a negative number, which contradicts the hypothesis that $c_{y}^{\prime}$ is a relatively real number . 
a six-dimensional universe (at least) - 3 space-like dimensions against other 3 time-like dimensions 9 .

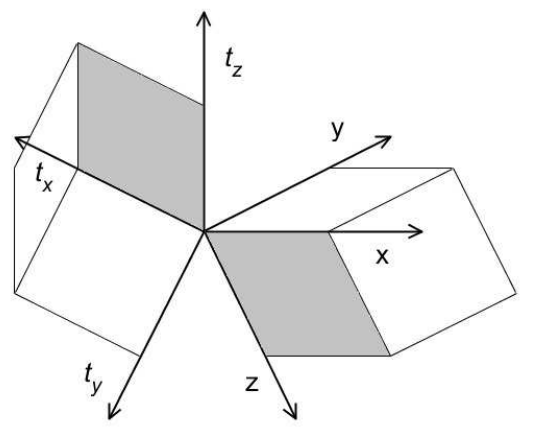

Figure 6: An illustration for the six-dimensional universe - "orthogonal universes."

But what is to be understood by a universe with three time-like dimensions? The interpretation we propose here is the following: although this universe has three time-like dimensions, the physical time, that is, the time which is actually measured by an observer, is always a one-dimensional quantity. Indeed, this physical time must match with the proper-time of the observer, that is, it should be determined by the world line length of the observer concerned.

Thus, for consistence, we should consider also that the other two time-like dimensions which are orthogonal to the observer's world line, should be always inaccessible to this observer. Therefore, although we regard the universe as six-dimensional in nature, the physical universe happens to be just four-dimensional. In such a way, this six-dimensional universe can be interpreted as consisting of two orthogonal dimensional universes of three dimension each 10 .

These interpretations enable us to define a sixdimensional metric for this universe by the expression

$$
d s=\sqrt{\left|c^{2} d t_{x}^{2}+c^{2} d t_{y}^{2}+c^{2} d t_{z}^{2}-d x^{2}-d y^{2}-d z^{2}\right|},
$$

${ }^{9}$ The conception of a six-dimensional universe also was already proposed before, see 4].

${ }^{10}$ The concept of "paralel universes" has been proposed, of couse, several times by the scientic fiction stories, but I cannot remember any of them who had introduced the concept of "orthogonal universes." and a physical metric by

$$
d \sigma=\sqrt{\left|c^{2} d t_{x}^{2}-d x^{2}-d y^{2}-d z^{2}\right|},
$$

where we suppose $t_{x}$ as the physical time measured by the observer (by a convenient choice of the coordinate system, this can always be done, of course).

Let us then show now how one can get the ELT in complete agreement with the relativity postulates presented in section 2. For this, let a particular event has coordinates $\left(c t_{x}, c t_{y}, c t_{z}, x, y, z\right)$ with respect to $R$, but suppose furthermore that only the coordinates $\left(c t_{x}, x, y, z\right)$ are accessible to this reference frame. Similarly, for the reference frame $R^{\prime}$ let $\left(c t_{x}^{\prime}, c t_{y}^{\prime}, c t_{z}^{\prime}, x^{\prime}, y^{\prime}, z^{\prime}\right)$ be the coordinates of that same event, and suppose now that only the coordinates $\left(c t_{x}^{\prime}, x^{\prime}, y^{\prime}, z^{\prime}\right)$ are accessible to $R^{\prime}$.

Let we analyze first the case where $v<c$. It is evident in this case that the accessible dimensions to $R$ and $R^{\prime}$ should coincide themselves (in fact, this is true for $v=0$ and therefore the result must continuity requirement). Thus, we obtain directly that the transformations should be just the usual Lorentz transformations, plus the relations

$$
c t_{y}^{\prime}=c t_{y}, \quad c t_{z}^{\prime}=c t_{z}, \quad y^{\prime}=y, \quad z^{\prime}=z .
$$

Consider now the more interesting case where $v>c$. Here, on the contrary, there must be a reversal of the accessible dimensions of $R$ when they are observed by $R^{\prime}$. Indeed, one might say, for instance, that the frames of reference $R$ and $R^{\prime}$ are now in differents "orthogonal universes." Thus, the coordinates $c t_{y}$ and $c t_{z}$ should become accessible to $R^{\prime}$, while the coordinates $y$ and $z$ should become inaccessible to him. Note also that the necessary condition for the light propagates in spherical surfaces with speed $c$ in both frames of reference is only that one has $d \sigma^{\prime}=d \sigma=0$ for rays of light. Nevertheless, we can consider a stronger hypothesis, namely, that in the six-dimensional universe the light propagates accordingly the equation $d s^{\prime}=d s=0$. In this case it is easy to verify that the previous condition is satisfied as well if we write

$$
c t_{y}^{\prime}= \pm y, \quad c t_{z}^{\prime}= \pm z, \quad y^{\prime}= \pm c t_{y}, \quad z^{\prime}= \pm c t_{z}
$$

which must to be added to the expressions

$$
c t_{x}^{\prime}= \pm \frac{c t_{x}-x v / c}{\sqrt{v^{2} / c^{2}-1}}, \quad x^{\prime}= \pm \frac{x-v t_{x}}{\sqrt{v^{2} / c^{2}-1}},
$$


already deduced in the section 4 . These equations constitute the ELT related to this six-dimensional universe. Notice, in special, that all coordinates are real.

Let us finally interpret the results. In the first place, is easy to see that in both frames of reference light propagates with speed $c$. This can be done by direct substitution of (58) and (59) into (56). In addition, notice that in this formulation, tachyons might be observed in the reference $R$ with a shape very different from what they present to $R^{\prime}$ because to the reference $R$ the transverse coordinates are given by $y= \pm c t_{y}^{\prime}$ and $z= \pm c t_{z}^{\prime}$, which are not accessible to $R^{\prime}$.

Further, it is interesting to notice that if a source of light is fixed to the frame $R^{\prime}$, then the frame $R$ should see the light propagating in spherical surfaces with speed $c$, as we had shown. But since the source has in this case a velocity greater than $c$, we must have the formation of a Mach cone in fact, since the source is always ahead from the waves which it emits. One can show that the superposition of waves emitted by a superluminal source results at two front waves whose shapes have the form of a two-sheet hyperboloid surface. The group velocity of these waves depends on the direction, being always larger than $c$ (except in the direction $X$ whose velocity equals $c$ ). This, however, is due purely to an interference phenomenon, unlike the cases of the previous formulations, which this phenomenon was due to a anisotropy of space-time itself.

This kind of waves are often called " $X$ waves", they are superluminal solutions of the Maxwell's equations [21, 22 - these waves have indeed been observed and even produced in the laboratory $3,21,22,23$. This is an important experimental verification of the existence of superluminal phenomena in nature.

\section{Acknowledgments}

The Author is grateful to Prof. Dr. A. Lima-Santos by reading the manuscript and by their suggestions. The Author also thanks to the Fundação de Amparo à Pesquisa do Estado de São Paulo for financial support.

\section{References}

[1] T. Adam et Al. (The OPERA Collaboration), Measurement of the neutrino velocity with the OPERA detector in the CNGS beam, arXiv:1109.4897v1 [hep-ex], p. 1-24, (2011).

[2] R.S. Vieira, Para Além da Velocidade da Luz - Uma Breve Introdução à Teoria dos Tachyons, Palestra apresentada na $7^{\text {a }}$ Semana da Física da Universidade Federal de São Carlos, São Carlos, (2011).

[3] E. Recami, Superluminal motions? A bird-eye view of the experimental situation, Found. Phys., 31, p. 1119-1135, (2001).

[4] E. Recami, Classical Tachyons and Possible Applications, Riv. Nuovo Cim. vol. 9, s. 3, n. 6, p. 1-178, (1986).

[5] H. Poincaré, Sur la dynamique de l'électron, Circ. Mat. Palermo, 21, p. 129-176 (1906).

[6] H. Minkowski, Raum und Zeit, Phys. Z. 10, p. 104-111, (1909).

[7] P.A.M. Dirac, A Teory of electrons and protons, Proc. R. Soc. London, A 126, p. 360-365 (1930).

[8] E.C.G. Stückelberg, Remarque a Propos de la Création de Paires de Particules en Théorie de Relativité, Helv. Phys. Acta, 14, p. 588-594, (1941).

[9] E.C.G. Stückelberg, La mécanique du point matériel en théorie de relativité et en théorie des quanta, Helv. Phys. Acta, 15, p. 23-37, (1942).

[10] R.P. Feynman, Space-Time Approach to Quantum Electrodynamics, Phys. Rev. 76, p. 769-789, (1949).

[11] R.P. Feynman, The reason for antiparticles, in Elementary Particles and the Laws of Physics, The 1986 Dirac Memorial Lectures by R.P. Feynman and S. Weinberg, (Cambridge University Press, Cambridge, 1987).

[12] O.M.P. Bilaniuk, V.K. Deshpande e E.C.G. Sudarshan, "Meta" Relativity, Am. Journ. Phys., 30, p. 718-723, (1962). 
[13] F. Catoni et Al., The Geometry of Minkowski Space-Time, (Springer Briefs in Physics, 2011).

[14] J. Vaz Jr., A Álgebra Geométrica do Espaço-tempo e a Teoria da Relatividade, Rev. Bras. Ens. Física, 22, p. 5-31, (2000).

[15] R.C. Tolman, The Theory of Relativity of Motion, (Berkeley, 1917).

[16] A. Einstein, Über die vom Relativitätsprinzip geforderte Trägheit der Energie, Ann. d. Phys. 23, p. 371-384, (1907).

[17] D. Bohm, The Special Theory of Relativity, (New York, 1965).

[18] E. Recami, The Tolman 'antitelephone' paradox: It's solution by tachyon mechanics, Lett. Nuovo Cim. 44, p. 587-593, (1985).

[19] E. Recami, Tachyon kinematics and causality: A systematic, thorough analysis of the tachyon causal paradoxes, Found. Phys., 17, p. 239-296 (1987).

[20] R.L. Dawe, K.C. Hines, The Physics of Tachyons I. Tachyon Kinematics, Aust. J. Phys. 45, p. 591-620, (1992).

[21] E.C. de Oliveira, W.A. Rodrigues Jr., Soluções Superluminais de Enegia finita das Equações de Maxwell, Tend. Mat. Apl. Comput., 3, p. 165-171, (2002).

[22] E. Recami, M.Z. Rached, Localized Waves: A not-so-short Review, Advances in Imaging \& Electron Physics, 156, p. 235-355, (2009).

[23] E. Recami, M. Fracastoro-Decker, W.A. Rodrigues Jr., Táquions, Revista Ciência Hoje, 5, n. 26, p. 48-59 (1986); E. Recami, M.Z. Rached, Mais velozes que a luz? Revista Ciência Hoje, 29, n. 170, p. 20-25 (2001). 


\title{
Uma Introdução à Teoria dos Táquions
}

\author{
(An Introduction to the Theory of Tachyons)
}

\author{
Ricardo S. Vieira* \\ Departamento de Física, Universidade Federal de São Carlos, São Carlos, SP, Brasil
}

\section{Resumo}

A teoria da relatividade, proposta no início do século $\mathrm{XX}$, aplica-se à partículas e referenciais cuja velocidade é menor que a velocidade da luz. Nesse artigo mostraremos como esta teoria pode ser estendida à partículas e referenciais que se movimentam mais rapidamente que a luz.

The theory of relativity, which was proposed in the beginning of the 20th century, applies to particles and frames of reference whose velocity is less than the velocity of light. In this paper we shall show how this theory can be extended to particles and frames of reference which move faster than light.

\section{Sobre a necessidade de se for- mular uma teoria dos táquions}

Cientistas do Centro Europeu de Pesquisas Nucleares (CERN) divulgaram recentemente os resultados de um experimento [1] onde provavelmente foram detectados neutrinos mais rápidos que a luz. Por coincidência, cerca de uma semana antes da divulgação desse resultado, tive a felicidade de apresentar na $7^{\text {a }}$ Semana da Física da UFSCar [2] uma palestra justamente sobre o tema dos táquions (nome dado em física teórica às partículas mais rápidas que a luz). Essa palestra gerou grande interesse por parte de professores e alunos, o qual foi ainda mais aumentado após a divulgação da notícia comentada acima. Desde então tenho sido incentivado a escrever um artigo sobre as ideias apresentadas naquela ocasião, o que me propus a fazer nessas últimas semanas e cujo resultado constitui o presente texto.

\footnotetext{
*E-mail: rsvieira@df.ufscar.br.
}

Estando ou não corretos os resultados apresentados em [1], mencionamos que existem outras evidências experimentais sobre a existência de fenômenos superluminais na natureza [3] e, independentemente disso, que a teoria dos táquions permite uma melhor compreensão da própria teoria da relatividade, bem como de alguns temas de mecânica quântica. Acreditamos que esses sejam motivos suficientes para se formular uma teoria $d a$ relatividade estendida que se aplique também a fenômenos, partículas e referenciais mais rápidos que a luz. Tentativas de se estender a teoria da relatividade já foram, é claro, propostas por diversos cientistas, muito embora as fontes originais não sejam de fácil acesso (com efeito, só tive conhecimento desses trabalhos recentemente). Dentre as formulações propostas, destacamos a formulação apresentada por Recami [4] e colaboradores, cujos resultados coincidem em sua grande maioria com os que serão apresentados aqui. A referência 4] consiste em um artigo de revisão sobre o assunto, onde o leitor interessado encontrará uma vasta quantidade de referências e poderá obter também mais detalhes sobre a teoria, além de tópicos que não serão discutidos aqui (e.g., a eletrodinâmica de táquions).

Por uma teoria da relatividade estendida, queremos nos referir a uma teoria que se aplique à partículas e referenciais que se movimentam com velocidades maiores que a da luz, bem como à partículas e referenciais que se "movimentam" para trás no tempo. Em especial é necessário estender as transformações de Lorentz para tais referenciais. Embora essa extensão possa ser deduzida, sem maiores problemas, em um universo de duas dimensões, $(x, t)$, nos deparamos com dificuldades ao tentarmos estendê-las em um universo de quatro dimensões, $(x, y, z, t)$. As razões pelas quais isso ocorre serão comentadas na seção 10. Por fim, na seção 11 mostraremos que em um universo de seis dimensões (com três dimensões espaciais e três temporais), 
àquelas dificuldades desaparecem e torna-se possível estender as transformações de Lorentz de acordo com os princípios da relatividade usual.

Um dos motivos que tornam a teoria dos táquions quase que desconhecida é a convicção (equivocada) de que a teoria da relatividade proíbe a existência de partículas mais velozes que a luz, e que essa velocidade representa um limite máximo para a propagação de qualquer fenômeno. Um dos argumentos geralmente empregados para provar essa afirmação é que, conforme estabelece a teoria da relatividade, nenhuma partícula pode ser acelerada até atingir, ou ultrapassar, a velocidade da luz, já que para isso seria necessário se gastar uma quantidade infinita de energia. Isso não está errado, porém, também não está completamente correto. Com efeito, esse argumento não leva em conta a possibilidade de que essas partículas possam ter sido criadas no exato momento da criação do universo - assim, ninguém teve de acelerá-las, elas simplesmente já nasceram com uma velocidade maior que a da luz.

Além disso, não podemos descartar a possibilidade de que tais partículas possam ser criadas através de algum processo quântico, análogo por exemplo ao processo de criação de pares de partículas-antipartículas.

Por fim, se associarmos uma completa isotropia e homogeneidade ao espaço-tempo, então segue que nenhuma de suas direções deve ser privilegiada em relação às outras e, portanto, a existência de partículas mais rápidas que a luz deveria ser naturalmente esperada, ao invés de ser encarada com surpresa. Não é a possibilidade de existência dos táquions que requer explicação, pelo contrário, uma explicação deveria ser dada caso essas partículas não existissem.

\section{Sobre a estrutura do espaço- tempo}

Como se sabe, a formulação da teoria da relatividade deveu-se ao esforço de vários cientistas (e.g., Lorentz, Poincaré, Einstein, Minkowski etc.). A descrição geométrica da teoria da relatividade - a chamada teoria do espaço-tempo -, por sua vez, foi proposta primeiramente por Poincaré [5] em 1905 e, depois, de maneira mais acessível e detalhada por Minkowski [6] em 1909.

Essa descrição geométrica, que contém a própria essência da teoria da relatividade, pode ser fundamentada nas seguintes afirmações, ou postulado: 1 .

\footnotetext{
${ }^{1} \mathrm{~A}$ influência da gravidade será explicitamente desprezada
}

1. O universo é um continuum em 4 dimensões - três dessas dimensões estão associadas às dimensões espaciais usuais $X, Y$ e $Z$, enquanto que a outra está associada a uma dimensão temporal, $T$.

2. O espaço-tempo é homogêneo e isotrópico.

3. A geometria do universo é hiperbólico-circular. Nos planos puramente espaciais, $X Y, Y Z$ e $Z X$ a geometria é circular (i.e., euclidiana), enquanto que nos planos que envolvem a dimensão temporal, $T X, T Y$ e $T Z$, a geometria é hiperbólica (i.e., pseudo-euclidiana).

Em termos da descrição de Poincaré-Minkowski, qualquer referencial inercial pode ser representado por um sistema de coordenadas adequado, que chamaremos de sistema de coordenadas inercial. O movimento de uma partícula fica representada por uma curva contínua uma reta, caso a velocidade da partícula seja constante -, a que chamamos de linha de universo da partícula. Em especial, a velocidade de uma partícula determinase pela tangente do ângulo (hiperbólico) que sua linha de universo faz com o eixo do tempo do sistema de coordenadas no qual a velocidade é referida. Analogamente, a velocidade relativa entre dois referenciais, $v$, é determinada pela tangente do ângulo (hiperbólico) entre os eixos de tempo dos sistemas de coordenadas correspondentes e uma mudança de referencial consiste, nessa descrição geométrica, a uma mera rotação hiperbólica 2 dos eixos coordenados.

Através dos postulados apresentados acima, toda a teoria da relatividade pode ser formulada. Em especial, destacamos que a partir desses postulados podemos mostrar o princípio de invariância da velocidade da luz (pelo menos em duas dimensões). De fato, o simples fato de que a geometria do espaço-tempo é hiperbólica implica a existência de uma classe de partículas cuja velocidade é sempre a mesma para qualquer referencial inercial. Podemos nos convencer disso ao notar que em uma geometria hiperbólica existem certas retas (as assíntotas) que não se alteram quando uma rotação hiperbólica é implementada. Se, portanto, a linha de universo de uma partícula for paralela a uma dessas assíntotas, a sua direção será sempre a mesma para qualquer sistema de coordenadas inercial e, consequentemente, a sua velocidade também será sempre a mesma

\footnotetext{
nesse texto.

${ }^{2}$ No caso em que $|v|>c$ devemos considerar uma rotação hiperbólica estendida, conforme será discutido na seção 4
} 
para qualquer referencial inercial. O fato experimental de que da velocidade luz é a mesma em qualquer referencial inercial fornece, assim, um forte argumento a favor do caráter hiperbólico do espaço-tempo.

Para uso futuro, faremos algumas definições e convenções que serão utilizadas durante o texto. Uma vez que estamos dispostos a levar em consideração partículas que se "movimentam" em qualquer direção do espaço-tempo, convém empregarmos uma métrica que seja sempre real e não-negativa. Optamos, assim, por definir a métrica pela expressão,

$$
d s=\sqrt{\left|c^{2} d t^{2}-d x^{2}-d y^{2}-d z^{2}\right|} .
$$

A escolha da métrica, é claro, não interfere nos resultados finais da teoria, uma vez que se tem certa liberdade em defini-la.

Em termos da métrica (11), vamos classificar os eventos como do tipo tempo, luz ou espaço conforme a quantidade $c^{2} d t^{2}-d x^{2}-d y^{2}-d z^{2}$ seja positiva, nula ou negativa, respectivamente. Uma classificação semelhante pode ser atribuída a partículas e referenciais. Assim, por exemplo, partículas mais lentas que a luz (brádions) serão classificadas como partículas do tipo tempo e partículas mais rápidas que a luz (táquions) como partículas do tipo espaço. Partículas que se movem com a velocidade da luz (luxons) serão classificadas, é claro, como partículas do tipo luz.

Também classificaremos as partículas de acordo com a sua "direção de movimento" no tempo. Partículas que se movimentam para o futuro serão chamadas de progressivas e as que se movimentam para o passado, de retrógradas. Partículas que se movimentam com velocidade infinita só existem no instante presente e por isso serão chamadas de momentâneas. Uma classificação idêntica pode ser empregada à referenciais.

\section{Antipartículas e o Princípio da Inversão}

$\mathrm{Na}$ seção anterior introduzimos o conceito de partículas retrógradas como partículas que voltam no tempo. Nessa seção vamos esclarecer como elas podem ser interpretadas do ponto de vista físico. Para que a discussão se torne mais simples, entretanto, vamos considerar apenas partículas do tipo tempo, isto é, partículas cuja velocidade é menor que a da luz.

Deixe-nos começar o nosso estudo analisando qual deve ser a energia de uma partícula retrógrada. Sabe- mos da teoria da relatividade usual que a energia de uma partícula (do tipo tempo) relaciona-se com sua massa e seu momentum através da expressão $E^{2}=$ $p^{2} c^{2}+m^{2} c^{4}$. Essa expressão quadrática tem duas soluções para a energia: uma raiz positiva e outra negativa (geometricamente, esta equação descreve, para $m$ fixo, um hiperboloide de duas faces). Na teoria relatividade geralmente interpretamos os estados de energia positiva como estados acessíveis a qualquer partícula progressiva, ou, em outras palavras, que uma partícula progressiva possui sempre uma energia positiva. Em virtude dessa associação, decorre que, por consistência, devemos interpretar os estados de energia negativa como acessíveis somente às partículas retrógradas, ou, em outros termos, que qualquer partícula retrógrada deve possuir uma energia negativa.

Esses dois conceitos que separadamente não possuem sentido físico - a saber, partículas que voltam no tempo e partículas livres de energia negativa -, podem ser conciliados através do que se chama de princípio da inver$s \tilde{a}{ }^{3}$. Esse princípio baseia-se no fato de que qualquer observador considera o tempo como que fluindo do passado para o futuro e que qualquer medição da energia de uma partícula livre resulta em uma quantidade positiva. Desse modo, o princípio da inversão estabelece que uma partícula retrógrada (cuja energia é negativa) deve sempre ser fisicamente observada como uma partícula progressiva usual (cuja energia é positiva).

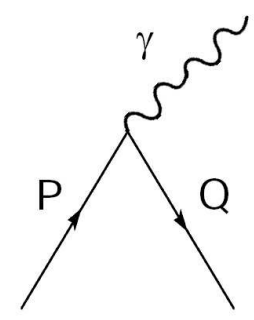

Figura 1: A partícula progressiva $P$ interage com o fóton $\gamma$ e se transforma na partícula retrógrada $Q$.

O leitor poderia pensar assim que não há diferenças entre partículas progressivas e retrógradas, já que aparentemente as últimas são sempre vistas como às primeiras. No entanto, isso não é bem assim, pois

\footnotetext{
${ }^{3}$ Switching principle, em inglês. Às vezes o termo "principio da reinterpretação" é também empregado.
} 
ao observarmos uma partícula retrógrada como progressiva, algumas de suas propriedades acabam por se inverterem no processo. Por exemplo, se a partícula retrógrada tem uma carga elétrica $+e$, então devido ao princípio de conservação de carga elétrica, devemos observar a "partícula invertida" como que portando a carga $-e$. Isso pode ser mais bem visualizado através da seguinte experiência.

Considere o fenômeno descrito na figura 1, onde uma partícula progressiva $P$, de carga elétrica $+e$, interage com um fóton $\gamma$ e que, em virtude dessa interação, se torne uma partícula retrógrada, $Q$. Note que a partícula $Q$ é, em verdade, a própria partícula $P$ mas que agora se "movimenta" para trás no tempo. Portanto, a carga elétrica da partícula $Q$ é também $+e$.

Entretanto, quando esse processo for fisicamente observado, o observador fará uso do princípio da inversão (mesmo que de maneira inconsciente) e o fenômeno passa a ser interpretado da seguinte forma: duas partículas de igual massa se aproximam e, em dado momento, colidem e se aniquilam, dando origem a um fóton. Desde que o fóton não tem carga elétrica e sabemos que a carga elétrica observada da partícula progressiva é $+e$, decorre que a carga elétrica observada da partícula retrógrada tem de ser $-e$. A conclusão que se tira disso é que o sinal da carga elétrica de uma partícula retrógrada se inverte no processo de observação.

Assim, uma partícula retrógrada de massa $m$ e carga $e$ é sempre vista como uma partícula progressiva de mesma massa e carga elétrica oposta. Ora, essas são justamente as propriedades esperadas de uma antipartícula. Portanto o princípio da inversão nos permite concluir que qualquer partícula retrógrada é observada fisicamente como uma antipartícula. O conceito de antipartículas pode ser visto, assim, como um conceito puramente relativístico; não é necessário se falar de mecânica quântica para se introduzir esse conceitd4.

Por fim, deixe-nos comentar que esses argumentos também são válidos no caso de partículas do tipo espaço, ou seja, no caso dos táquions. No entanto, veremos na seção 8 que no caso dos táquions a energia se relaciona com o momentum e a massa através da relação $E^{2}=p^{2} c^{2}-m^{2} c^{4}$, equação esta que descreve um hiperboloide de folha única. Assim podemos verificar

${ }^{4}$ A conexão entre partículas que voltam no tempo com antipartículas já foi, é claro, proposta por diversos cientistas (e.g., Dirac [7, Stückelberg [8], Feynman [10] 11, Sudarshan [12], Recami 4 etc.). que os táquions possuem uma propriedade bem interessante: eles podem passar de uma partícula progressiva a uma retrógrada (e vice-versa) através de um simples movimento contínuo. Em outras palavras, ao acelerarmos um táquion podemos fazê-lo se transformar em um antitáquion e vice-versa (no momento dessa inversão, aliás, o táquion tornar-se-ia uma partícula momentânea, ou seja, uma partícula de velocidade infinita). Isso, é claro, só é possível para partículas do tipo espaço.

\section{Dedução das transformações de Lorentz estendidas (em 2 di- mensões)}

Deixe-nos agora mostrar como as transformações de Lorentz podem ser generalizadas, ou estendidas, à referenciais que se movimentam com uma velocidade maior que a da luz, bem como para referenciais retrógrados. Nessa seção nos limitaremos, contudo, a formular uma teoria em duas dimensões. Como já foi comentado, em quatro dimensões nos deparamos com diversas dificuldades para se fazer essa extensão, as quais serão explicadas na seção 10. Apresentaremos a seguir duas deduções para as Transformações de Lorentz Estendidas (TLE), uma dedução algébrica e outra geométrica.

Dedução Algébrica: desde que, em duas dimensões, os postulados apresentados na seção anterior são suficientes para mostrar que a luz se propaga com mesma velocidade $c$ em qualquer referencial inercial, podemos tomar esse resultado como o nosso ponto de partida.

Considere assim que um determinado evento tenha as coordenadas $(c t, x)$ em relação a um referencial $R$ e que para um outro referencial inercial $R^{\prime}$, que se movimenta em relação a $R$ com velocidade $v$, as coordenadas desse mesmo evento sejam $\left(c t^{\prime}, x^{\prime}\right)$. Suponha além disso que os eixos coordenados desses referenciais sejam igualmente orientados e que em $t^{\prime}=t=0$, a origem dos referenciais coincidam 5 .

Nessas condições, se um raio de luz for emitido da origem do referencial $R$ e no instante $t=0$, então esse raio de luz se propagará, em relação a $R$, conforme a

\footnotetext{
${ }^{5}$ Daqui em diante, sempre que falarmos nos referenciais $R$ e $R^{\prime}$ assumiremos implicitamente que a velocidade relativa entre eles é $v$ e que as condições estabelecidas acima são sempre satisfeitas.
} 
equação

$$
x^{2}-c^{2} t^{2}=0,
$$

e, para $R^{\prime}$, devido ao princípio de invariância da velocidade da luz, conforme

$$
x^{\prime 2}-c^{2} t^{\prime 2}=0
$$

(2) e (3) implica, portanto, que

$$
x^{\prime 2}-c^{2} t^{\prime 2}=\lambda(v)\left(x^{2}-c^{2} t^{2}\right),
$$

onde $\lambda(v)$ não depende das coordenadas e do tempo, mas pode depender de $v$.

Por outro lado, desde que a velocidade do referencial $R$ quando medida por $R^{\prime}$ é claramente $-v$, segue também que

$$
x^{2}-c^{2} t^{2}=\lambda(-v)\left(x^{\prime 2}-c^{2} t^{\prime 2}\right) .
$$

Conclui-se, assim, a partir de (4) e (5), que $\lambda(v) \lambda(-v)=1$. Entretanto, a hipótese de que o espaçotempo é isotrópico e homogêneo impede que $\lambda(v)$ possa depender da direção da velocidade e somos levados à condição

$$
\lambda(v)^{2}=1 \quad \Rightarrow \quad \lambda(v)= \pm 1
$$

Temos assim dois casos à considerar. Deixe-nos primeiro considerar o caso em que $\lambda(v)=+1$. Nesse caso a equação (4) se torna

$$
x^{\prime 2}-c^{2} t^{\prime 2}=x^{2}-c^{2} t^{2},
$$

e, como sabemos, a solução de (7) nos leva diretamente às transformações de Lorentz usuais,

$$
c t^{\prime}=\frac{c t-x v / c}{\sqrt{1-v^{2} / c^{2}}}, \quad x^{\prime}=\frac{x-v t}{\sqrt{1-v^{2} / c^{2}}} .
$$

Note que essas transformações contém a identidade (para $v=0$ ) e são descontínuas apenas em $v=$ $\pm c$. Consequentemente, essas transformações devem se aplicar a todo o intervalo $-c<v<c$, e somente a esse intervalo.

Esperamos assim que no outro caso, isto é, quando $\lambda(v)=-1$, as transformações encontradas estejam relacionadas à velocidades maiores que a da luz. Mostraremos agora que de fato é isso o que ocorre.

\footnotetext{
${ }^{6}$ De fato, é apenas nesse caso que as transformações procuradas formam um grupo, conferir 5 .
}

Para $\lambda(v)=-1$, a equação (4) se torna

$$
x^{\prime 2}-c^{2} t^{\prime 2}=-\left(x^{2}-c^{2} t^{2}\right),
$$

Através das substituições formais $x \rightarrow \pm i \xi$ e $c t \rightarrow$ $\pm i c \tau$, podemos reescrever (9) como

$$
x^{2}-c^{2} t^{\prime 2}=\xi^{2}-c^{2} \tau^{2} .
$$

A equação (10) tem a mesma forma que a equação (17) e, portanto, admite mesma solução:

$$
c t^{\prime}=\frac{c \tau-\xi v / c}{\sqrt{1-v^{2} / c^{2}}}, \quad x^{\prime}=\frac{\xi-v \tau}{\sqrt{1-v^{2} / c^{2}}} .
$$

Expressando novamente essas equações em termos de $x$ e $t$, obtemos

$$
c t^{\prime}= \pm \frac{c t-x v / c}{\sqrt{v^{2} / c^{2}-1}}, \quad x^{\prime}= \pm \frac{x-v t}{\sqrt{v^{2} / c^{2}-1}}
$$

e agora só nos resta remover a ambiguidade dos sinais presente nessas transformações. O sinal correto, contudo, depende das "direções de movimento" dos referenciais $R$ e $R^{\prime}$ no espaço-tempo, conforme pode ser visualizado na figura 2. No caso de uma transformação progressiva do tipo espaço, facilmente se pode mostrar que o sinal correto é o negativo.

Note que essas equações, assim como no caso anterior, são descontínuas apenas em $v= \pm c$, mas agora elas são reais somente quando $|v|>c$. Essas equações representam, por conseguinte, as transformações de Lorentz entre dois referenciais progressivos cuja velocidade relativa é maior que a da luz, onde o sinal correto depende se o referencial $R^{\prime}$ é progressivo ou retrógrado em relação à $R$ e pode ser visualizado na figura 2 .

Dedução Geométrica: do ponto de vista geométrico, as TLE correspondem a uma rotação (hiperbólica) definida sobre a curva 7

$$
\left|c^{2} t^{2}-x^{2}\right|=\rho^{2}
$$

\footnotetext{
${ }^{7}$ Tal rotação pode ser mais elegantemente descrita através do conceito de números hiperbólicos 13 . Um número hiperbólico é um número da forma $z=a+h b$, com $\{a, b\} \in \mathbb{R}$ e $h:\left\{h^{2}=+1, h \notin \mathbb{R}\right\}$. Definindo-se o conjugado $\bar{z}=a-h b$, segue que $|\overline{z z}|=\left|a^{2}-b^{2}\right|=\rho^{2}$, uma equação da mesma forma que (13). Obtém-se assim uma completa analogia com os números complexos, mas com a diferença de que agora esses números descrevem uma geometria hiperbólica. Destacamos também que o mesmo pode ser feito através da chamada álgebra geométrica do espaço-tempo [14, com a vantagem de que esse formalismo talvez permita uma generalização à dimensões maiores.
} 
Podemos chamar tal transformação de rotação hiperbólica estendida. Note que (13) representa um par de hipérboles equiláteras e ortogonais. As duas assíntotas

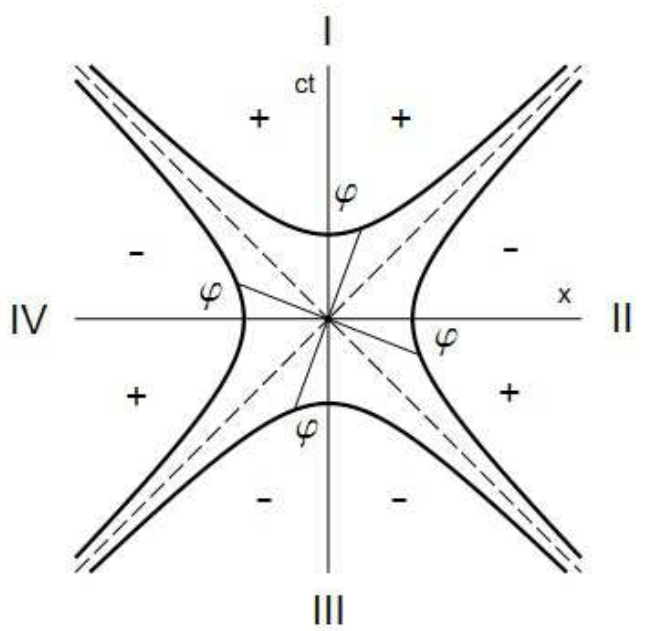

Figura 2: Gráfico da Curva $\left|c^{2} t^{2}-x^{2}\right|=\rho^{2}$.

dessa curva dividem o plano em quatro regiões desconexas, a que chamaremos de regiões I, II, III e IV, respectivamente (ver figura 2).

Para expressar tal rotação, convém introduzir as funções hiperbólicas estendidas, $\cosh \theta$ e $\sinh \theta$, definido-as através das relações

$$
c t=\rho \cosh \theta, \quad x=\rho \sinh \theta,
$$

onde $0 \leq \theta<2 \pi$ é o parâmetro circular usual e $\rho$ é dado por (13). Note que nessa descrição geométrica a velocidade passa a ser dada pela expressão

$$
v / c=\tanh \theta .
$$

As expressões de $\cosh \theta$ e $\sinh \theta$, por sua vez, podem ser determinadas através das funções hiperbólicas usuais, $\cosh \varphi$ e $\sinh \varphi$, onde $\varphi$ é o parâmetro hiperbólico, $-\infty<\varphi<\infty$. De fato, se introduzirmos em cada região do plano um parâmetro hiperbólico $\varphi$ correspondente, o qual deve ser medido, por conveniência, como mostrado na figura 2, então as funções $\cosh \varphi$ e $\sinh \varphi$ nos permitem parametrizar cada um dos ramos da curva (13). Assim, uma vez especificada a região na qual $\theta$ pertence, $\rho$ e $\varphi$ determinam de forma única qualquer ponto da curva (13) e, portanto, determinam também as funções hiperbólicas estendidas. Com essas convenções, encontramos que

$$
\begin{gathered}
\cosh \theta \equiv \begin{cases}+\cosh \varphi, & \theta \in \mathrm{I} \\
-\sinh \varphi, & \theta \in \mathrm{II} \\
-\cosh \varphi, & \theta \in \mathrm{III} \\
+\sinh \varphi, & \theta \in \mathrm{IV}\end{cases} \\
\sinh \theta \equiv \begin{cases}+\sinh \varphi, & \theta \in \mathrm{I} \\
+\cosh \varphi, & \theta \in \mathrm{II} \\
-\sinh \varphi, & \theta \in \mathrm{III} \\
-\cosh \varphi, & \theta \in \mathrm{IV}\end{cases}
\end{gathered}
$$

onde os parâmetros $\theta$ e $\varphi$ relacionam-se através da fórmula

$$
\tan \theta=\tanh \theta \equiv\left\{\begin{array}{ll}
+\tanh \varphi, & \theta \in(\mathrm{I}, \mathrm{III}) \\
-\operatorname{coth} \varphi, & \theta \in(\mathrm{II}, \mathrm{IV})
\end{array} .\right.
$$

As expressões das funções hiperbólicas estendidas também podem ser encontradas sem se fazer uso das funções hiperbólicas usuais. Para isso parametrizamos (13) através das funções circulares, colocando $c t=$ $r \cos \theta$ e $x=r \sin \theta$, onde $r=\sqrt{c^{2} t^{2}+x^{2}}$. Isso nos permite escrever diretamente,

$$
\cosh \theta=\frac{\cos \theta}{\sqrt{|\cos 2 \theta|}}, \quad \sinh \theta=\frac{\sin \theta}{\sqrt{|\cos 2 \theta|}} .
$$

ou, em termos da tangente,

$$
\cosh \theta=\frac{\sigma(\theta)}{\sqrt{\left|1-\tan ^{2} \theta\right|}}, \quad \sinh \theta=\frac{\sigma(\theta) \tan \theta}{\sqrt{\left|1-\tan ^{2} \theta\right|}},
$$

com

$$
\sigma(\theta)=\left\{\begin{array}{ll}
+1, & -\pi / 2<\theta<\pi / 2 \\
-1, & \pi / 2<\theta<3 \pi / 2
\end{array} .\right.
$$

A equivalência entre (16) e (18) ou (19) é encontrada quando se leva em conta (17).

Uma vez definidas as funções hiperbólicas estendidas é fácil obter as expressões que descrevem uma rotação hiperbólica estendida. Sejam $(c t, x)=$ $\left(\rho \cosh \theta_{1}, \rho \sinh \theta_{1}\right)$, as coordenadas de um ponto do plano para um sistema de coordenadas $R$, o qual supomos pertencer ao setor I do espaço-tempo. Se efetuarmos uma rotação hiperbólica passiva (i.e., dos eixos coordenados), digamos por um ângulo $\theta_{12}$, vamos obter um novo sistema de coordenadas $R^{\prime}$ e as coordenadas 


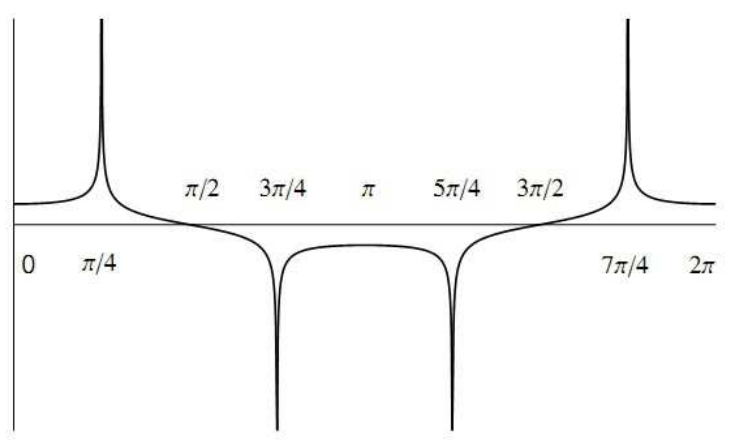

Figura 3: Gráfico da função hiperbólica estendida, $\cosh \theta$. O gráfico da função $\sinh \theta$ é semelhante a este, mas com uma defasagem de $\pi / 2 \mathrm{rad}$.

daquele mesmo ponto passarão a ser dadas agora por $\left(c t^{\prime}, x^{\prime}\right)=\left(\rho \cosh \theta_{2}, \rho \sinh \theta_{2}\right)$. Como $\theta_{12}=\theta_{1}-\theta_{2}$, segue que

$$
c t^{\prime}=\rho \cosh \left(\theta_{1}-\theta_{12}\right), \quad x^{\prime}=\rho \sinh \left(\theta_{1}-\theta_{12}\right) .
$$

Substituindo as expressões de $\cosh \left(\theta_{1}-\theta_{12}\right)$ e $\sinh \left(\theta_{1}-\theta_{12}\right)$ por qualquer uma das expressões acima e simplificando as expressões resultantes, levando-se ainda em conta (17), pode-se verificar que $\left(c t^{\prime}, x^{\prime}\right)$ relaciona-se com $(c t, x)$ através das equações

$$
\begin{aligned}
& c t^{\prime}=\delta\left(\theta_{12}\right)\left(c t \cosh \theta_{12}-x \sinh \theta_{12}\right), \\
& x^{\prime}=\delta\left(\theta_{12}\right)\left(x \cosh \theta_{12}-c t \sinh \theta_{12}\right),
\end{aligned}
$$

onde

$$
\delta(\theta)=\left\{\begin{array}{ll}
+1, & \tan ^{2} \theta<1 \\
-1, & \tan ^{2} \theta>1
\end{array} .\right.
$$

Por fim, utilizando (19) e colocando $\tan \theta_{12}=v / c$, obtemos diretamente as transformações procuradas, que são idênticas às obtidas algebricamente:

$$
c t^{\prime}=\varepsilon\left(\theta_{12}\right) \frac{c t-x v / c}{\sqrt{\left|1-v^{2} / c^{2}\right|}}, \quad x^{\prime}=\varepsilon\left(\theta_{12}\right) \frac{x-v t}{\sqrt{\left|1-v^{2} / c^{2}\right|}}
$$

onde fizemos $\varepsilon\left(\theta_{12}\right)=\sigma\left(\theta_{12}\right) \delta\left(\theta_{12}\right) \cdot \varepsilon\left(\theta_{12}\right)$ determina o sinal que deve figurar na frente dessas transformações, conforme pode ser visto na figura 2 .

\section{A lei de composição de veloci- dades e as transformações in- versas}

As transformações deduzidas na seção anterior formam um grupo, no qual as transformações de Lorentz ordinárias constituem apenas um subgrupo. Deixe-nos demonstrar essa estrutura.

Em primeiro lugar, notemos que a identidade é obtida quando se faz $v=0$. Mostraremos agora que a composição de duas TLE resulta ainda em outra TLE. Para isso introduzimos um terceiro referencial inercial $R^{\prime \prime}$, que se movimenta em relação a $R^{\prime}$ com velocidade $u=c \tanh \theta_{23}$. Por outro lado, supomos que o referencial $R^{\prime}$ movimenta-se com a velocidade $v=c \tanh \theta_{12}$ em relação a $R$. A lei de transformação entre $R$ e $R^{\prime}$ já conhecemos, e pode ser escrita como

$$
\begin{aligned}
& c t^{\prime}=\varepsilon\left(\theta_{12}\right) \frac{c t-x \tanh \theta_{12}}{\sqrt{\left|1-\tanh ^{2} \theta_{12}\right|}}, \\
& x^{\prime}=\varepsilon\left(\theta_{12}\right) \frac{x-c t \tanh \theta_{12}}{\sqrt{\left|1-\tanh ^{2} \theta_{12}\right|}} .
\end{aligned}
$$

Por sua vez, a lei de transformação de $R^{\prime}$ para $R^{\prime \prime}$ pode ser escrita por uma expressão análoga:

$$
\begin{aligned}
& c t^{\prime \prime}=\varepsilon^{\prime}\left(\theta_{23}\right) \frac{c t^{\prime}-x^{\prime} \tanh \theta_{23}}{\sqrt{\left|1-\tanh ^{2} \theta_{23}\right|}}, \\
& x^{\prime \prime}=\varepsilon^{\prime}\left(\theta_{23}\right) \frac{x^{\prime}-c t^{\prime} \tanh \theta_{23}}{\sqrt{\left|1-\tanh ^{2} \theta_{23}\right|}} .
\end{aligned}
$$

Nessas equações, $\varepsilon^{\prime}\left(\theta_{23}\right)$ determina os sinais correspondentes às transformações de $R^{\prime}$ para $R^{\prime \prime}$, os quais não precisam necessariamente ser iguais aos sinais presentes nas transformações de $R$ para $R^{\prime}$. De fato, enquanto na definição de $\varepsilon\left(\theta_{12}\right)$ o referencial de partida, $R$, era suposto pertencer à região I do espaço-tempo, o referencial $R^{\prime}$ pode pertencer a qualquer região. Assim, $\varepsilon^{\prime}\left(\theta_{23}\right)$ é uma função ainda a se determinar.

A substituição de (25) em (26) nos fornece a lei de transformação entre $R$ e $R^{\prime \prime}$. Após algumas simplificações, pode-se verificar que as expressões obtidas pos- 
suem a mesma forma de uma TLE, a saber,

$$
\begin{aligned}
& c t^{\prime \prime}=\varepsilon^{\prime \prime}\left(\theta_{13}\right) \frac{c t-x \tanh \left(\theta_{13}\right)}{\sqrt{\left|1-\tanh ^{2}\left(\theta_{13}\right)\right|}} \\
& x^{\prime \prime}=\varepsilon^{\prime \prime}\left(\theta_{13}\right) \frac{x-c t \tanh \left(\theta_{13}\right)}{\sqrt{\left|1-\tanh ^{2}\left(\theta_{13}\right)\right|}} .
\end{aligned}
$$

onde,

$$
\varepsilon^{\prime \prime}\left(\theta_{13}\right)=\frac{\varepsilon\left(\theta_{12}\right) \varepsilon^{\prime}\left(\theta_{23}\right)}{\delta\left(\theta_{12}, \theta_{23}\right)}
$$

com

$$
\delta\left(\theta_{12}, \theta_{23}\right)=\left\{\begin{array}{ll}
+1, & \tanh \theta_{12} \tanh \theta_{23}<1 \\
-1, & \tanh \theta_{12} \tanh \theta_{23}>1
\end{array},\right.
$$

$\mathrm{e}$

$$
\tanh \left(\theta_{13}\right)=\frac{\tanh \theta_{12}+\tanh \theta_{23}}{1+\tanh \theta_{12} \tanh \theta_{23}}=\tanh \left(\theta_{12}+\theta_{23}\right) .
$$

Através de (17) podemos verificar que (30) consiste em uma generalização da fórmula de adição das tangentes hiperbólicas, o que revela o seu significado geométrico. Em termos das velocidades, a equação (30) pode ser reescrita como

$$
w=\frac{u+v}{1+u v / c^{2}} .
$$

A equação (31) expressa à lei de composição de velocidades em nossa teoria. Ela é exatamente igual à expressão obtida na teoria da relatividade usual, mas agora aplica-se a quaisquer valores de velocidade.

Podemos igualmente mostrar que existe a transformação inversa. Para isso podemos colocar em (27) as condições $c t^{\prime \prime}=c t$ e $x^{\prime \prime}=x$, e requerer que a transformação resultante seja a identidade. Assim verificamos que é necessário se ter $\theta_{23}=-\theta_{12}$ e $\varepsilon^{\prime \prime}\left(\theta_{13}\right)=1$. Com essas condições torna-se possível calcular $\varepsilon^{\prime}\left(\theta_{23}\right)$ através da expressão resultante de $\varepsilon^{\prime \prime}\left(\theta_{13}\right)$. De fato, encontramos que

$$
\varepsilon^{\prime}\left(\theta_{23}\right)=\delta\left(\theta_{12}\right) / \varepsilon\left(\theta_{12}\right)=\sigma\left(\theta_{12}\right),
$$

já que $\delta\left(\theta_{12},-\theta_{12}\right)=\delta\left(\theta_{12}\right)$, com $\delta\left(\theta_{12}\right)$ definido por (23).

Substituindo esse resultado em (26) obtemos então, em termos das velocidades, as expressões procuradas das transformações inversas,

$$
\begin{aligned}
& c t=\varepsilon^{-1}\left(\theta_{12}\right) \frac{c t^{\prime}+x^{\prime} v / c}{\sqrt{\left|1-v^{2} / c^{2}\right|}} \\
& x=\varepsilon^{-1}\left(\theta_{12}\right) \frac{x^{\prime}+v t^{\prime}}{\sqrt{\left|1-v^{2} / c^{2}\right|}}
\end{aligned}
$$

onde colocamos $\varepsilon^{-1}\left(\theta_{12}\right)=\sigma\left(\theta_{12}\right)$. Note que os sinais das transformações inversas diferem dos que aparecem nas transformações diretas. Essa diferença devese ao fato já comentado de que de que na transformação $R \rightarrow R^{\prime}$, assumimos que o referencial de partida pertencia sempre à região I do espaço-tempo, enquanto que na transformação inversa, $R^{\prime} \rightarrow R$, é o referencial de chegada que fixamos à região I. Quando $|v|<c$ essa assimetria não interfere em nada, já que nesse caso os sinais são sempre iguais nas duas definições, contudo, no caso em que $|v|>c$, decorre que as transformações inversas não podem ser obtidas simplesmente pela substituição de $v$ por $-v$, ainda é necessário multiplicá-las por -1 .

Por fim, mencionamos que a associatividade das TLE pode ser igualmente demonstrada, o que completa a sua estrutura de grupo.

\section{Referenciais conjugados}

Introduziremos agora um importante conceito que só pode ser contemplado em uma teoria estendida da relatividade: o conceito de referenciais conjugados. A definição é a seguinte: dois referenciais são ditos serem conjugados se a velocidade relativa entre eles for infinita. Assim, se considerarmos o referencial $R^{\prime}$, que lembremos - se movimenta com velocidade $v$ em relação a $R$, o referencial conjugado a $R^{\prime}$ consiste em um referencial $R^{*}$ cuja velocidade é, em relação a $R$, igual a $w=c^{2} / v$. De fato, obtemos de (31),

$$
\lim _{u \rightarrow \infty}\left(\frac{u+v}{1+u v / c^{2}}\right)=\frac{c^{2}}{v}
$$

A importância do conceito de referenciais conjugados provém do fato de que uma transformação do tipo espaço entre dois referenciais, digamos, entre $R$ e $R^{\prime}$, pode ser obtida por uma transformação de Lorentz usual entre os referenciais $R$ e $R^{*}$, bastando para isso fazer as substituições $v \rightleftharpoons c^{2} / v, c t^{*} \rightleftharpoons x$ e $x^{*} \rightleftharpoons c t$. De 
fato, desde que $w=c^{2} / v$ é menor que $c$ para $v>c$, segue que a transformação de $R$ para $R^{*}$ é dada por

$$
c t^{*}=\frac{c t-x w / c}{\sqrt{1-w^{2} / c^{2}}}, \quad x^{*}=\frac{x-w t}{\sqrt{1-w^{2} / c^{2}}} .
$$

E pode-se verificar que, efetuando-se as substituições indicadas acima, obtém-se as transformações corretas entre $R$ e $R^{\prime}$.

Do ponto de vista geométrico a passagem de um referencial para o seu conjugado consiste em uma reflexão dos seus eixos coordenados em relação às assíntotas da curva (13), já que tal reflexão tem justamente o efeito de trocar $c t$ por $x$ e vice-versa (e, consequentemente, o de substituir $v$ por $\left.c^{2} / v\right)$. Vemos assim que uma transformação de Lorentz estendida pode ser reduzida a uma transformação de Lorentz usual através de apropriadas reflexões em torno das assíntotas (para o caso das transformações do tipo espaço) e em torno da origem (para uma transformação retrógrada do tipo tempo). Isso nos fornece uma nova maneira de se deduzir as TLE.

É interessante notar que se uma partícula tem velocidade $u=c^{2} / v$ em relação ao referencial $R$, então ela terá uma velocidade infinita para o referencial $R^{\prime}$, ou seja, ela será uma partícula momentânea para esse referencial. Assim, podemos verificar que se a velocidade da partícula for $u>c^{2} / v$ e, além disso, tivermos $v<c$, então essa partícula se tornará retrógrada para $R^{\prime}$, e será observada como uma antipartícula por esse referencial. Se, do contrário, tivermos $v>c$, então o referencial $R^{\prime}$ observará uma antipartícula sempre que $u<c^{2} / v$.

Desde que a velocidade relativa do referencial $R^{\prime} \mathrm{em}$ relação a $R$ é $-v$, decorre também que uma partícula de velocidade $u^{\prime}=-c^{2} / v$ terá velocidade infinita em $R$. Assim, no caso em que se tem $|v|<c$, o referencial $R$ verá uma antipartícula se $u^{\prime}<-c^{2} / v$, e no caso em que $|v|>c$, ele só observará uma antipartícula se $u^{\prime}>-c^{2} / v$. Essas relações, é claro, podem ser mais facilmente encontradas pela análise (30) ou (31).

\section{Réguas e relógios}

Considere dois relógios idênticos, mas com um deles fixo no referencial $R$, enquanto que o outro é fixo no referencial $R^{\prime}$. Desejamos comparar o ritmo de funcionamento desses relógios, quando medido por um desses referenciais. Por exemplo, suponha que desejamos comparar o ritmo do relógio fixo em $R^{\prime}$ com o relógio fixo em $R$, quando ambos os relógios são medidos por $R$. Para isso, considere que para o referencial $R^{\prime}$, o seu relógio leve o tempo $\tau^{\prime}$ para dar uma oscilação completa. O tempo $T$ correspondente a essa oscilação para o referencial $R$ pode ser encontrado através das transformações inversas (33), se lembrarmos que $\Delta x^{\prime}=0$, já que o relógio analisado está fixo em $R^{\prime}$. Obtemos assim que

$$
T=\varepsilon^{-1}(\theta) \frac{\tau^{\prime}}{\sqrt{\left|1-v^{2} / c^{2}\right|}} .
$$

Podemos então verificar que um relógio progressivo (em relação a $R$ ) em movimento trabalha em um ritmo mais lento que um relógio em repouso quando a sua velocidade for menor que a da luz (como, aliás, é bem sabido). Mas para um relógio mais rápido que a luz, o seu ritmo de funcionamento continua a ser menor para $|v / c|<\sqrt{2}$ e passa a ser maior quando $|v / c|>\sqrt{2}$. É interessante notar que para $|v / c|=\sqrt{2}$ ambos os relógios voltam a funcionar no mesmo ritmo. Além disso, no caso de um relógio retrógrado, o relógio em movimento marcará o tempo de trás para frente, o que expressa o simples fato de que relógios retrógrados devem marcar o tempo no sentido do futuro para o passado.

Deixe-nos agora verificar como o relógio fixo em $R$ se comporta em relação ao relógio de $R^{\prime}$, quando os tempos são medidos por esse último referencial. Nesse caso devemos utilizar as transformações diretas e obtemos

$$
T^{\prime}=\varepsilon(\theta) \frac{\tau}{\sqrt{\left|1-v^{2} / c^{2}\right|}},
$$

onde $\tau$ é o tempo gasto pelo relógio fixo em $R$ (i.e., que se move com velocidade $-v$ para $R^{\prime}$ ) para dar uma oscilação completa, quando esse tempo é medido por $R$. Agora, o sinal que aparece em (37) é determinado conforme a figura (2) e a análise se torna pouco mais ou menos complicada. É claro que não há problemas quando $|v|<c$, passemos então a analisar o caso em que $|v|>c$. Suponha primeiro que o referencial $R^{\prime}$ seja progressivo em relação a $R$. Nesse caso encontramos que $\varepsilon(\theta)=-1$ e o relógio que para $R^{\prime}$ se movimenta com velocidade $-v$ trabalha no sentido contrário ao do relógio fixo em $R^{\prime}$. Isso significa que o relógio de $R$ é retrógrado em relação à $R^{\prime}$. Que isso é verdade pode ser verificado através do que foi comentado na seção anterior, onde se deve notar que $u=0$ e $|v|>c$ (e que, por conseguinte, $\left.u<c^{2} / v\right)$.

No entanto, essa é uma situação interessante porque acabamos de ver que para o referencial $R$, o relógio em 
movimento funciona no mesmo sentido que o seu relógio, em repouso. Assim, enquanto um dos referenciais insiste que os relógios funcionam ao contrário, o outro discorda, afirmando que ambos os relógios trabalham no mesmo sentido! No caso em que o referencial $R^{\prime}$ é retrógrado em relação a $R$ a assimetria ainda persiste, mas agora é o referencial $R$ que verá ambos os relógios funcionarem no sentido contrário, enquanto que para $R^{\prime}$ os relógios funcionarão no mesmo sentido. Essa assimetria, é claro, tem origem na própria assimetria entre as transformações diretas e inversas.

Considere agora duas réguas idênticas, uma colocada no referencial $R$ e outra no referencial $R^{\prime}$. Desejamos comparar o comprimento dessas réguas, quando analisadas por um desses referenciais. Se $l_{0}^{\prime}$ é o comprimento da régua fixa em $R^{\prime}$ quando medida por esse referencial, então o seu comprimento $L$, como medido por $R$, é obtido ao se determinar onde se encontram os estremos da régua em movimento em um dado instante $t$. Fazendo uso das transformações diretas, encontramos que

$$
L=\varepsilon(\theta) \cdot l_{0}^{\prime} \sqrt{\left|1-v^{2} / c^{2}\right|} .
$$

Para $|v|<c$ reencontramos à contração de Lorentz, mas para $|v|>c$ obtemos que a régua em movimento será menor que a régua em repouso quando $|v / c|<\sqrt{2}$ e voltará a ter o mesmo comprimento quando $|v / c|=$ $\sqrt{2}$. Por fim, para $|v / c|>\sqrt{2}$ teremos uma "dilatação de Lorentz." Além disso, considerando que o referencial $R^{\prime}$ é progressivo em relação a $R$, decorre que para $R$ a régua em movimento estará orientada contrariamente a sua régua, em repouso.

Se, por outro lado, as medições são feitas por $R^{\prime}$, então encontramos que

$$
L^{\prime}=\varepsilon^{-1}(\theta) \cdot l_{0} \sqrt{\left|1-v^{2} / c^{2}\right|},
$$

e agora para $R^{\prime}$ a régua em movimento (que tem velocidade $-v$ ) apontará para o mesmo sentido que a sua régua em repouso. Encontramos assim as mesmas assimetrias comentadas mais acima.

Esses resultados podem, é claro, ser obtidos - e mais bem compreendidos - através dos diagramas de Minkowski.

\section{Dinâmica}

Nesta seção pretendemos responder a algumas questões referentes à dinâmica dos táquions. As expressões para a energia e o momentum de uma partícula mais rápida que a luz serão deduzidas e mostraremos como tais partículas se comportam quando na presença de um campo de forças.

Como ponto de partida assumiremos que o princípio da ação estacionária aplica-se também à partículas mais rápidas que a luz. Isso, é claro, segue diretamente da hipótese de que o espaço-tempo é isotrópico e homogêneo, uma vez que sabemos que esse princípio é válido para partículas mais lentas que a luz.

Como se sabe, o princípio da ação estacionária afirma que existe uma quantidade $S$, chamada ação, que assume um valor extremo (máximo ou mínimo) para qualquer movimento possível de um sistema mecânico (no nosso caso, uma partícula). Por outro lado, na ausência de forças o movimento de uma partícula corresponde a uma geodésica do espaço-tempo, a qual se reduz a uma reta quando desprezamos a gravitação. Isso significa que no caso de uma partícula livre a diferencial da ação $d S$ deve ser proporcional ao elemento de linha $d s$ da partícula e podemos escrever

$$
d S=\alpha d s, \quad d s=\sqrt{\left|c^{2} d t^{2}-d x^{2}-d y^{2}-d z^{2}\right|} .
$$

Temos de enfatizar, entretanto, que a constante de proporcionalidade $\alpha$ pode assumir valores diferentes em regiões diferentes do espaço-tempo, uma vez que essas regiões são completamente desconexas. Portanto, é conveniente considerar cada caso separadamente.

No caso de uma partícula progressiva do tipo tempo, (40) assume a forma,

$$
d S=\mathcal{L}(u) d t, \quad \mathcal{L}(u)=\alpha c \sqrt{1-u^{2} / c^{2}}
$$

onde introduzimos a função de LaGrange, $\mathcal{L}(u)$, para expressar a ação em termos da velocidade da partícula.

Como se sabe, as expressões para a energia e momentum são obtidas pelas fórmulas

$$
p(u)=\frac{\partial \mathcal{L}(u)}{\partial u}, \quad E(u)=u\left[\frac{\partial \mathcal{L}(u)}{\partial u}\right]-\mathcal{L}(u) .
$$

Aplicando-se (42) em (41) obtemos, assim,

$$
p(u)=-\frac{\alpha u / c}{\sqrt{1-u^{2} / c^{2}}}, \quad E(u)=-\frac{\alpha c}{\sqrt{1-u^{2} / c^{2}}} .
$$

Para determinar $\alpha$ podemos usar o fato de que essas expressões devem, para baixas velocidades, se reduzir às expressões obtidas pela mecânica de Newton. Assim, por exemplo, se expandirmos a expressão para o momentum em uma série de potências de $u / c$ e 
retermos apenas o primeiro termo, encontramos que $p \approx-\alpha u / c$, ao passo que a mecânica de Newton nos fornece $p=m u$. Assim obtemos $\alpha=-m c$ e ficamos com

$$
p(u)=\frac{m u}{\sqrt{1-u^{2} / c^{2}}}, \quad E(u)=\frac{m c^{2}}{\sqrt{1-u^{2} / c^{2}}},
$$

que são justamente as expressões conhecidas da relatividade usual.

Já caso de uma partícula progressiva do tipo espaço (i.e., no caso de um táquion progressivo), a função de LaGrange assume a forma

$$
\mathcal{L}(u)=\alpha c \sqrt{u^{2} / c^{2}-1} .
$$

E obtemos, por meio de (42), as seguintes expressões para o momentum e energia dessa partícula,

$$
p(u)=\frac{\alpha u / c}{\sqrt{u^{2} / c^{2}-1}}, \quad E(u)=\frac{\alpha c}{\sqrt{u^{2} / c^{2}-1}} .
$$

A constante $\alpha$, entretanto, não pode mais ser calculada através da comparação dessas expressões com as que são obtidas na mecânica de Newton, já que a velocidade da partícula é nesse caso sempre maior que a da luz. Mas podemos, em contrapartida, calcular o limite dessas expressões para quando $u \rightarrow \infty$, e assim encontramos que

$$
\lim _{u \rightarrow \infty} p(u)=\alpha, \quad \lim _{u \rightarrow \infty} E(u)=0,
$$

de onde se pode ver que $\alpha$ é igual ao momentum de uma partícula momentânea, ou seja, de velocidade infinita.

Desde que a massa de uma partícula deve ser um invariante universal, segue que podemos definir uma métrica também no espaço da energia e dos momenta. Fazendo uma analogia com (1), podemos definir essa métrica dinâmica como

$$
c^{2} d m=\sqrt{\left|d E^{2}-c^{2} d p_{x}^{2}-c^{2} d p_{y}^{2}-c^{2} d p_{z}^{2}\right|} .
$$

Assim, segue que a massa, a energia e o momentum de uma partícula devem estar relacionados sempre pela fórmula $m c^{2}=\sqrt{\left|E^{2}-c^{2} p^{2}\right|}$. Se colocarmos, nessa última equação, $E=0$, obtemos que $p=m c=\alpha$ (onde assumimos $p$ é positivo para $u$ positivo). E assim concluímos que o momentum e a energia de um táquion são dadas pelas as expressões

$$
p(u)=\frac{m u}{\sqrt{u^{2} / c^{2}-1}}, \quad E(u)=\frac{m c^{2}}{\sqrt{u^{2} / c^{2}-1}} .
$$
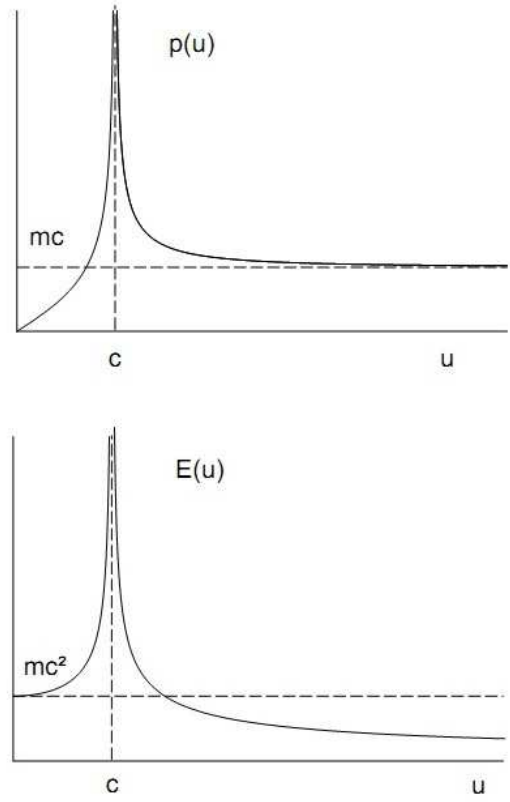

Figura 4: Gráficos para o momentum e energia de uma partícula progressiva com velocidade $0 \leq u<\infty$.

Esse resultado pode também ser obtido através do emprego dos referenciais conjugados, introduzidos na seção 6. Suponha que uma partícula tenha velocidade $u>c$ para um referencial $R$. Então para o referencial conjugado $R^{*}$ ela terá energia $E^{*}=c p$ e momentum $p^{*}=E / c$, enquanto que a sua velocidade passa a ser $w=c^{2} / u$, que é menor que $c$. Mas as expressões para o momentum e energia de um brádion (i.e., de uma partícula do tipo tempo) são dadas por (42), e obtemos, por conseguinte,

$$
p^{*}=\frac{m w}{\sqrt{1-w^{2} / c^{2}}}, \quad E^{*}=\frac{m c^{2}}{\sqrt{1-w^{2} / c^{2}}} .
$$

Podemos assim verificar que as substituições de $E^{*}, p^{*}$ e $w$ nas fórmulas acima resultam exatamente na expressão (49).

No caso de partículas retrógradas, a função de LaGrange troca de sinal, já que $d t$ é negativo e $\mathcal{L}=d S / d t$. Por conseguinte, partículas retrógradas devem ter energia negativa, um resultado que já havíamos indicado na seção 3.

Por fim, deixe-nos mostrar como uma partícula do tipo espaço deve se comportar quando submetida a um 
campo de forças. A força que atua na partícula continua, é claro, sendo dada pela lei de Newton, $\dot{p}=F$, mas agora $p$ é dado por (49). Calculando a derivada, obtemos

$$
F=-\frac{m a}{\left(u^{2} / c^{2}-1\right)^{3 / 2}},
$$

onde $a=d u / d t$ denota a aceleração da partícula. Note que a força é dirigida no sentido oposto à aceleração. Consequentemente duas partículas do tipo espaço que dinamicamente se atraem (se repelem) devem se afastar (se aproximar) uma da outra. Os conceitos de atraçãoaproximação e de repulsão-afastamento, portanto, não são mais equivalentes quando lidamos com táquions. De fato, se tentássemos se aproximar (ou se afastar) de um táquion, a sua velocidade relativa diminuiria (aumentaria), um efeito que é contrário ao nosso senso comum mas que pode ser demonstrado por uma simples análise de 31).

\section{Causalidade e o paradoxo de Tolman}

Um dos argumentos geralmente empregados para se mostrar que partículas mais rápidas que a luz não podem existir é que a sua existência implicaria uma violação do princípio de causalidade. Com efeito, suponha que um táquion seja emitido por um corpo $A$ no instante $t_{A}$ e que ele seja absorvido por outro corpo $B$ no instante $t_{B}$, onde $t_{B}>t_{A}$. Como esses dois eventos (emissão de um táquion por $A$ e sua absorção por $B$ ) estão separados por uma distância do tipo espaço, sabemos da teoria da relatividade que é possível encontrar um outro referencial, com velocidade menor que a da luz, onde a ordem cronológica desses eventos se inverte. Assim, se assumirmos que o evento em $A$ é a causa do evento $B$, então chegaremos a conclusão de que, para esse referencial em movimento, o efeito precede a sua causa.

Portanto, se admitirmos que os conceitos de causa e efeito são absolutos, e que a causa sempre precede o seu efeito, então efetivamente somos levados a conclusão de que partículas mais rápidas que a luz não podem existir. No entanto, não há nada do ponto de vista matemático que dê suporte a essa hipótese. Pelo contrário, se admitirmos uma completa isotropia e homogeneidade do espaço e tempo, então não temos outra escolha senão considerar os conceitos de causa e efeito como conceitos relativos.
Já vimos, é claro, outras quantidades que eram consideradas absolutas na teoria da relatividade usual e passaram agora a serem vistas como que relativas. Um exemplo é o conceito de emissão e absorção. Com efeito, uma vez que pelo princípio da inversão não observamos partículas retrógradas mas sim antipartículas progressivas, os processos de emissão (absorção) de partículas retrógradas são sempre observadas como uma absorção (emissão) de antipartículas. Podemos, é claro, descobrir se uma partícula foi de fato emitida (absorvida) se analisarmos o processo no referencial onde a fonte (emissor) está em repouso, nesse caso falaremos de uma emissão (absorção) intrínseca ou própria.

O caráter relativo da causalidade, todavia, não leva a nenhuma contradição à teoria. Na natureza, um fenômeno nunca descreve um evento isolado, mas sim uma sucessão contínua de eventos, ou seja, um processo físico. Geometricamente um processo descreve uma curva contínua no espaço-tempo e portanto tem um caráter absoluto: a ordem temporal com que os eventos ocorrem podem diferir de referencial para referencial, mas a curva em si, que corresponde ao fenômeno em questão, é a mesma para qualquer um deles. Isso, por exemplo, é suficiente para mostrar que não podemos voltar no tempo e matar o nosso avô. De fato, o simples fato de existirmos significa que existe uma curva no espaço tempo conectando o nosso avô a nós e, por essa curva ter caráter absoluto, ela não pode ser (estar) desconectada por (para) qualquer observador, mesmo que este voltasse no tempo.
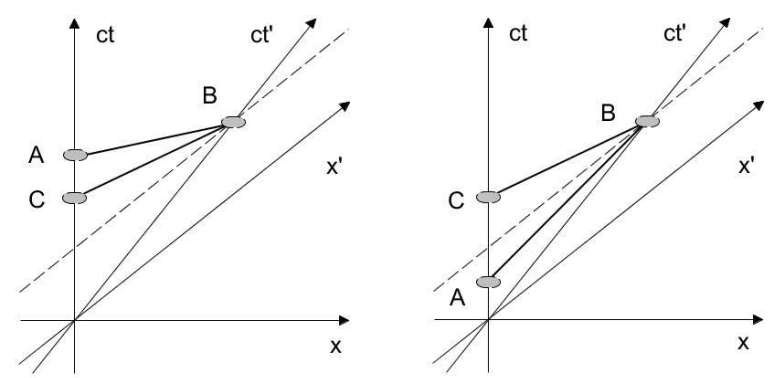

Figura 5: Experimento imaginado por Tolman.

Como exemplo de um paradoxo que envolve o conceito de causalidade, deixe-nos analisar o interessante paradoxo proposto e discutido por Tolman [15] em 1917, embora já tivesse sido apontado dez anos antes 
por Einstein em 16. Maiores detalhes podem ser conferidos em 17, 18, 19.

O paradoxo consiste em mostrar que se existissem partículas mais rápidas que a luz, então seria possível enviar informações para o passado. Para mostrar isso, considere que os referenciais $R$ e $R^{\prime}$ (com $R^{\prime}$ movendose com uma velocidade $v<c$ em relação a $R$ ) sejam equipados com certos aparelhos telefônicos especiais, cuja comunicação é feita através da transmissão de táquions. Imagine, assim, que um observador em $R$ envie (evento A) uma mensagem, digamos na forma de uma pergunta, para $R^{\prime}$ e que, após o seu recebimento (evento B), um observador em $R^{\prime}$ mande de volta para $R$ a sua resposta, que é então recebida por $R$ (evento C). Acontece que, como pode ser visto na figura 5 a, o observador em $R^{\prime}$ pode calibrar o seu aparelho de modo que a mensagem enviada por ele chegue em $R$ antes que esse observador tivesse enviado a sua pergunta. Assim, uma vez que $R$ obtém a resposta antes mesmo de fazer a pergunta, $R$ poderia deixar de fazê-la, mas caso ele tome essa decisão, também não poderia haver qualquer resposta por parte de $R^{\prime}$, o que constitui uma situação paradoxal.

A falha nessa argumentação é que ela mistura as descrições dos referenciais quando os termos "emissão" e "absorção" são empregados. De fato, mostraremos agora (seguindo 4]) que se o referencial $R^{\prime}$ receber intrinsecamente a pergunta enviada por $R$, e também enviar intrinsecamente a sua resposta, então o referencial $R$ sempre receberá a resposta de $R^{\prime}$ depois de ter enviado a sua pergunta.

Para isso, suponha que a pergunta de $R$ é enviada com uma velocidade $u_{1}$, e que a resposta volte com uma velocidade $u_{2}$, com ambas as velocidades maiores que a da luz e medidas por $R$. Então note que para a resposta de $R^{\prime}$ chegar antes da pergunta de $R$, é necessário que se tenha $\left|u_{1}\right|>\left|u_{2}\right|$, porque para $R$ o evento $C$ é anterior a $A$ e ambos chegam em $B$ no mesmo instante. No entanto, para que o referencial $R^{\prime}$ receba intrinsecamente a pergunta de $R$ é necessário que se tenha $\left|u_{1}\right|<c^{2} / v$, já que do contrário, conforme vimos na seção 6. essa mensagem seria retrógrada para $R^{\prime}$ e o observador em $R^{\prime}$ veria simplesmente a emissão de uma mensagem por meio da transmissão de antitáquions, conforme prediz o princípio da inversão. Da mesma forma, para que $R^{\prime}$ emita intrinsecamente a sua resposta, devemos ter $\left|u_{2}\right|>c^{2} / v$, já que a resposta é enviada na direção negativa do eixo $X$ de $R$. Assim, mostramos que $\left|u_{2}\right|>\left|u_{1}\right|$, uma contradição.
Portanto, se o referencial $R^{\prime}$ de fato recebe a pergunta de $R$ e de fato emite a sua resposta, então o processo será descrito, em verdade, pela figura 5 b e não pela figura 5a. Nesse caso, a resposta sempre chega depois de a pergunta ser enviada pelo referencial $R$.

É claro que a figura 5 a também representa um processo físico válido, mas não se refere efetivamente à situação descrita no paradoxo de Tolman. Além disso, cada referencial terá a sua própria visão do que ocorre. Por exemplo, para o referencial $R$ a figura 5 a corresponde ao caso onde, primeiramente, há o envio da mensagem $C$ (por meio de antitáquions) e, logo depois, o envio da mensagem $A$ (por meio de táquions), por fim, ambas as mensagens chegam juntas em $B$. Já para $R^{\prime}$ tudo se passa como se ele enviasse a mensagem $C$ para $R$ por meio de antitáquions e, ao mesmo tempo, enviasse a mensagem $A$ por meio de táquions, então após algum tempo ele veria que o observador em $R$ recebe a mensagem $C$ e depois a mensagem $A$. Note que a ordem cronológica dos eventos depende do referencial considerado, mas o processo em si (que interliga os eventos $A, B$ e $C$ ) é único.

\section{Dificuldades para se formular a teoria dos táquions em 4 di- mensões}

Na seção 4 conseguimos com êxito mostrar que em duas dimensões as transformações de Lorentz podem ser estendidas, de modo a relacionar qualquer par possível e imaginável de referenciais inerciais. Quando, porém, tentamos fazer o mesmo em quatro dimensões, nos deparamos com sérias dificuldades, as quais serão brevemente discutidas aqui.

Deixe-nos lembrar o leitor que ao estender as transformações de Lorentz em duas dimensões, fizemos o uso de um importante princípio: o que afirma que a velocidade da luz é a mesma em qualquer referencial inercial. Vimos, aliás, que esse princípio pode ser deduzido a partir dos postulados apresentados na seção 2, de modo que ele pode ser visto como um teorema da própria teoria da relatividade. Quando, todavia, passamos para um universo de 4 dimensões, não é mais possível mostrar a validade geral desse teorema da mesma forma que fizemos lá, de modo que em quatro dimensões não podemos nem mesmo afirmar que a luz se propaga em superfícies esféricas e com velocidade $c$ em 
qualquer referencial inercial.

Para mostrar mais claramente a origem dessa dificuldade, deixe-nos considerar por exemplo uma fonte de luz fixa na origem do referencial $R$ e supor que em relação a esse referencial a luz se propague em superfícies esféricas e com velocidade $c$. Em quatro dimensões as assíntotas do espaço-tempo são substituídas por um cone - o cone de luz. A região do espaço-tempo ocupada por um raio de luz que é emitida pela fonte fixa em $R$ sempre pertence a esse cone de luz.

A teoria da relatividade usual mostra também que para qualquer outro referencial inercial do tipo tempo, a propagação dessa luz é ainda representada por esse mesmo cone de luz. Mas como a luz deve se comportar para um referencial $R^{\prime}$ do tipo espaço? Nesse caso, o eixo do tempo desse referencial estará sempre na região externa ao cone de luz de $R$, de modo que não é evidente que a luz emitida pela fonte fixa em $R$ deva se propagar em superfícies esféricas de velocidade $c$ para $R^{\prime}$. Além disso, podemos nos perguntar o que acontece quando uma fonte fixa em $R^{\prime}$ emite luz. Será que para $R^{\prime}$ essa luz se propagará em superfícies esféricas de velocidade $c$ ? E para o referencial $R$, onde a fonte tem velocidade $v>c$, o que ocorre?

Como se pode ver, há várias questões que não podem ser respondidas de imediato, sem se ter informações adicionais. De fato, o comportamento da luz depende de suas propriedades intrínsecas, as quais são determinadas por uma teoria eletromagnética que a priori desconhecemos. Deixe-nos analisar um pouco mais essas possibilidades.

Podemos supor, por exemplo, que a fonte de luz fixa em $R^{\prime}$ (que vamos supor ter velocidade maior que a da luz) também emita ondas esféricas e com velocidade $c$ para esse mesmo referencial. Então agora deve existir um outro cone de luz, correspondente à esse referencial do tipo espaço e que deve contornar o eixo do tempo de $R^{\prime}$. Uma vez que o eixo do tempo de $R$ sempre estará fora desse novo cone de luz, segue que para $R$ a luz emitida pela fonte em movimento não se propagará em superfícies esféricas de velocidade $c$, mas antes terá a forma de um hiperboloide de dupla face. Nesse caso a velocidade dos raios luminosos dependeria, por conseguinte, da sua direção de propagação e o espaço-tempo não poderia mais ser considerado isotrópico.

Se, do contrário, considerarmos que a luz emitida pela fonte em $R^{\prime}$ se propaga em superfícies esféricas com respeito ao referencial $R$, ou seja, que no universo existe apenas um cone de luz, e que a luz sempre "per- corre" esse cone, não importando qual seja a velocidade da fonte que a emitiu, então podemos verificar que embora a luz se propague em superfícies esféricas de velocidade $c$ para $R$, o mesmo não ocorre para $R^{\prime}$, que observa a luz se propagar em hiperboloides de dupla face.

Para que a luz se propague em superfícies esféricas de velocidade $c$ em ambos os referenciais é necessário que as coordenadas transversais, $y^{\prime}$ e $z^{\prime}$, do referencial $R^{\prime}$ sejam imaginárias (assumindo que $y$ e $z$ são reais). Pois somente desse modo se pode mapear um cone de luz do "tipo tempo" em um cone de luz do "tipo espaço." Com efeito, isso pode ser mostrado ao se deduzir as TLE em 4 dimensões, assumindo desde o início a validade do princípio de invariância da velocidade da luz para qualquer referencial inercial. De fato, teremos nesse caso,

$$
x^{\prime 2}+y^{\prime 2}+z^{\prime 2}-c^{2} t^{\prime 2}=\lambda(v)\left(x^{2}+y^{2}+z^{2}-c^{2} t^{2}\right),
$$

no lugar de (4). Como se sabe, a solução dessa equação para $\lambda(v)=+1$ consiste nas transformações de Lorentz usuais, enquanto que, para $\lambda(v)=-1$ obtemos

$$
\begin{gathered}
c t^{\prime}= \pm \frac{c t-x v / c}{\sqrt{v^{2} / c^{2}-1}}, \quad x^{\prime}= \pm \frac{x-v t}{\sqrt{v^{2} / c^{2}-1}} \\
y^{\prime}= \pm i y, \quad z^{\prime}= \pm i z
\end{gathered}
$$

e as coordenadas transversais $y^{\prime}$ e $z^{\prime}$ tornam-se imaginárias. A introdução de coordenadas imaginárias é, no entanto, desprovida de qualquer sentido físicd 8 .

Se, por sua vez, negarmos a validade do princípio de invariância da velocidade da luz, então obtemos as

\footnotetext{
${ }^{8}$ Alguns autores, como por exemplo em [20, argumentam que a introdução de coordenadas imaginárias na teoria não constitui um problema. A solução apresentada por eles consiste em considerar os próprios eixos coordenados $Y^{\prime}$ e $Z^{\prime}$ como imaginários, de modo que os observadores do referencial (do tipo espaço) $R^{\prime}$ sempre interpretem as coordenadas $y^{\prime}$ e $x^{\prime}$ como relativamente reais. Isso, todavia, não é consistente. De fato, considere por exemplo um raio de luz que se propague na direção $Y$ do referencial $R$. Para o referencial $R^{\prime}$, a luz caminha por uma trajetória oblíqua, e as componentes de sua velocidade terão as magnitudes $\left|c_{x}^{\prime}\right|=v$ e $\left|c_{y}^{\prime}\right|=c \sqrt{v^{2} / c^{2}-1}$. Assim, para que o raio de luz se propague com a velocidade $c^{\prime}=c$, é estritamente necessário que o quadrado de $c_{y}^{\prime}$ seja um número negativo, o que contraria a hipótese de que $c_{y}^{\prime}$ é um número relativamente real.
} 
transformações

$$
\begin{gathered}
c t^{\prime}= \pm \frac{c t-x v / c}{\sqrt{v^{2} / c^{2}-1}}, \quad x^{\prime}= \pm \frac{x-v t}{\sqrt{v^{2} / c^{2}-1}} \\
y^{\prime}= \pm y, \quad z^{\prime}= \pm z
\end{gathered}
$$

em que todas as coordenadas são reais. O problema é que agora estamos nos casos discutidos anteriormente, onde o espaço-tempo não pode mais ser considerado isotrópico.

Note que em cada uma das possibilidades discutidas acima, as componentes transversais das grandezas físicas se tornarão diferentes. Assim, por exemplo, a formulação da eletrodinâmica dos táquions assumirá formas diferentes em cada uma dessas formulações. Somente a experiencia pode, contudo, decidir qual delas está correta, (isto é, assumindo que alguma delas esteja).

Em resumo, os argumentos apresentados acima nos mostram que não é possível estender as transformações de Lorentz de modo a satisfazer todos os postulados apresentados na seção 2, a não ser que se introduza quantidades imaginárias, o que não tem interpretação física. Veremos na seção seguinte que, se não exigirmos a validade do postulado 1 , isto é, que o universo tenha quatro dimensões, então torna-se possível construir uma teoria dos táquions que satisfaça os outros postulados.

\section{Uma possível teoria em 6 di- mensões}

Podemos nos perguntar por que encontramos dificuldades em estender as transformações de Lorentz em um universo de quatro dimensões, se em duas dimensões essa extensão é quase que direta. Após um pouco de reflexão, podemos encontrar a resposta. O motivo pelo o qual isso ocorre reside no fato de que em quatro dimensões temos um número diferente de dimensões espaciais e temporais. Desde que a experiência nos mostra que o universo tem três dimensões espaciais (pelo menos), segue que devemos considerar um universo de (no mínimo) seis dimensões - três do tipo tempo, três do tipo espaçd 9 .

\footnotetext{
${ }^{9} \mathrm{~A}$ concepção de um universo em seis dimensões também já foi proposta antes, conferir [4].
}

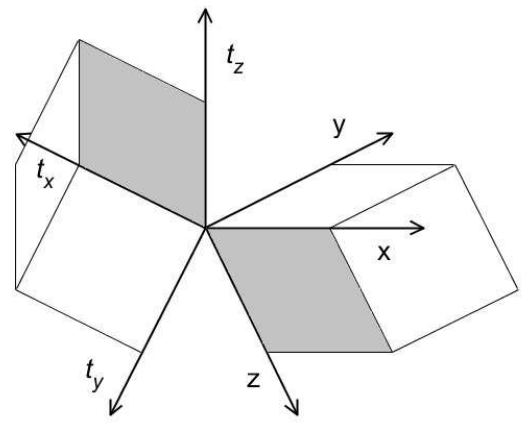

Figura 6: Ilustração de um universo em 6 dimensões "universos ortogonais."

Mas o que devemos entender por um universo com três dimensões de tempo? A interpretação que propomos aqui é a seguinte: embora o universo tenha três dimensões do tipo tempo, o tempo físico, isto é, o tempo que de fato é medido por um observador, é sempre unidimensional. Efetivamente, esse tempo físico deve corresponder ao tempo próprio desse observador, ou seja, deve ser determinado pelo comprimento de sua linha de universo.

Dessa forma, consideramos também que as outras duas dimensões do tipo tempo, as que são ortogonais à linha de universo do observador, são sempre inacessíveis a esse observador. Assim, muito embora o universo seja considerado hexadimensional nessa teoria, o universo físico é sempre quadridimensional. De certa forma, esse universo a seis dimensões pode ser interpretado como que composto por dois universos tridimensionais ortogonais 10 , conforme está pictoricamente ilustrado na figura 6 .

Com essas interpretações, podemos definir a métrica do universo em seis dimensões pela expressão

$$
d s=\sqrt{\left|c^{2} d t_{x}^{2}+c^{2} d t_{y}^{2}+c^{2} d t_{z}^{2}-d x^{2}-d y^{2}-d z^{2}\right|},
$$

e a métrica física por

$$
d \sigma=\sqrt{\left|c^{2} d t_{x}^{2}-d x^{2}-d y^{2}-d z^{2}\right|} .
$$

onde supomos que $t_{x}$ seja o tempo físico medido pelo

\footnotetext{
${ }^{10} \mathrm{O}$ conceito de "universos paralelos" já foi, é claro, apresentado em diversas histórias de ficção científica, entretanto, não me recordo de nenhuma delas ter introduzido a ideia de "universos ortogonais."
} 
observador correspondente (por uma escolha conveniente do sistema de coordenadas isso, é claro, pode sempre ser feito).

Deixe-nos então mostrar agora como se pode obter as TLE que estejam de acordo com os postulados apresentados na seção 2. Para isso, considere um determinado evento de coordenadas $\left(c t_{x}, c t_{y}, c t_{z}, x, y, z\right)$ em relação a um referencial $R$, mas que apenas as coordenadas $\left(c t_{x}, x, y, z\right)$ sejam acessíveis a esse referencial. Analogamente, para o referencial $R^{\prime}$ deixe $\left(c t_{x}^{\prime}, c t_{y}^{\prime}, c t_{z}^{\prime}, x^{\prime}, y^{\prime}, z^{\prime}\right)$ serem as coordenadas daquele mesmo evento, onde agora somente as coordenadas $\left(c t_{x}^{\prime}, x^{\prime}, y^{\prime}, z^{\prime}\right)$ são acessíveis a $R^{\prime}$.

Considere primeiro o caso em que $v<c$. Nesse caso é evidente que as dimensões acessíveis de $R$ e $R^{\prime}$ devem ser iguais, já que para $v=0$ devemos obter a identidade. Assim, obtemos diretamente que as transformações procuradas consistem nas transformações de Lorentz usuais, acrescidas das relações

$$
c t_{y}^{\prime}=c t_{y}, \quad c t_{z}^{\prime}=c t_{z}, \quad y^{\prime}=y, \quad z^{\prime}=z .
$$

Considere agora o caso de mais interesse em que $v>c$. Aqui, pelo contrário, deve haver uma inversão nas dimensões acessíveis de $R$ quando observadas por $R^{\prime}$. De fato, podemos dizer que os referenciais $R$ e $R^{\prime}$ estão, agora, em "universos ortogonais" diferentes. Assim, as coordenadas $c t_{y}$ e $c t_{z}$ devem passar a ser acessíveis para $R^{\prime}$, enquanto que as coordenadas $y$ e $z$ devem se tornar inacessíveis. Note ainda que para a luz se propagar em superfícies esféricas de velocidade $c \mathrm{em}$ ambos os referenciais é necessário apenas que se tenha $d \sigma=d \sigma^{\prime}=0$. Contudo, podemos considerar a hipótese mais forte de que sempre se tenha $d s^{\prime}=d s=0$ para um raio de luz. Nesse caso facilmente se verifica que condição anterior é satisfeita através das relações

$$
c t_{y}^{\prime}= \pm y, \quad c t_{z}^{\prime}= \pm z, \quad y^{\prime}= \pm c t_{y}, \quad z^{\prime}= \pm c t_{z},
$$

as quais se somam as expressões

$$
c t_{x}^{\prime}= \pm \frac{c t_{x}-x v / c}{\sqrt{v^{2} / c^{2}-1}}, \quad x^{\prime}= \pm \frac{x-v t_{x}}{\sqrt{v^{2} / c^{2}-1}},
$$

já deduzidas na seção 4, para constituir as TLE em seis dimensões. Note que agora todas as coordenadas são reais.

Deixe-nos por fim interpretar os resultados obtidos. Em primeiro lugar é fácil verificar que em ambos os referenciais a luz se propagará com velocidade $c$. Isso pode ser feito através da substituição direta de (58) e (59) em (56). Além disso, notemos que nessa formulação, a forma como os táquions são observados no referencial $R$ pode ser completamente diferente de sua forma para o referencial $R^{\prime}$, uma vez que para o referencial $R$ as coordenadas transversais são dadas por $y= \pm c t_{y}^{\prime}$ e $z= \pm c t_{z}^{\prime}$, as quais não são acessíveis a $R^{\prime}$.

Além disso, é interessante notar que se uma fonte de luz for fixada ao referencial $R^{\prime}$, então o referencial $R$ verá essa luz se propagando em superfícies esféricas com velocidade $c$, conforme mostramos, mas desde que a fonte tem nesse caso uma velocidade maior que $c$, teremos efetivamente a formação de um cone de Mach, pois a fonte estará sempre à frente das ondas que emite. Pode-se mostrar então que a superposição das ondas emitidas por essa fonte superluminal formam duas frentes de onda com o formato de hiperboloides. A velocidade de grupo dessas ondas depende da direção, sendo sempre maior que $c$ (exceto na direção $X$, cuja velocidade é $c$ ). Isso, no entanto, deve-se puramente a um fenômeno de interferência, diferentemente do que ocorria nos casos discutidos na seção anterior. Ondas desse tipo são comumente chamadas de "ondas $X$ " e efetivamente são soluções superluminais das equações de Maxwell [21, 22, - essas ondas, inclusive, já foram observadas e até mesmo produzidas em laboratório [3, 21, 22, 23, o que constitui uma importante verificação experimental da existência de fenômenos superluminais na natureza.

\section{Agradecimentos}

O autor agradece ao Prof. Dr. A. Lima-Santos pela leitura do manuscrito e sugestões, e também à Fundação de Amparo à Pesquisa do Estado de São Paulo (FAPESP) pelo suporte financeiro.

\section{Referências}

[1] T. Adam et Al. (The OPERA Collaboration), Measurement of the neutrino velocity with the OPERA detector in the CNGS beam, arXiv:1109.4897v1 [hep-ex], p. 1-24, (2011).

[2] R.S. Vieira, Para Além da Velocidade da Luz - Uma Breve Introdução à Teoria dos Tachyons, Palestra apresentada na $7^{\text {a }}$ 
Semana da Física da Universidade Federal de São Carlos, São Carlos, (2011).

[3] E. Recami, Superluminal motions? A bird-eye view of the experimental situation, Found. Phys., 31, p. 1119-1135, (2001).

[4] E. Recami, Classical Tachyons and Possible Applications, Riv. Nuovo Cim. vol. 9, s. 3, n. 6, p. 1-178, (1986).

[5] H. Poincaré, Sur la dynamique de l'électron, Circ. Mat. Palermo, 21, p. 129-176 (1906).

[6] H. Minkowski, Raum und Zeit, Phys. Z. 10, p. 104-111, (1909).

[7] P.A.M. Dirac, A Teory of electrons and protons, Proc. R. Soc. London, A 126, p. 360-365 (1930).

[8] E.C.G. Stückelberg, Remarque a Propos de la Création de Paires de Particules en Théorie de Relativité, Helv. Phys. Acta, 14, p. 588-594, (1941).

[9] E.C.G. Stückelberg, La mécanique du point matériel en théorie de relativité et en théorie des quanta, Helv. Phys. Acta, 15, p. 23-37, (1942).

[10] R.P. Feynman, Space-Time Approach to Quantum Electrodynamics, Phys. Rev. 76, p. 769-789, (1949).

[11] R.P. Feynman, The reason for antiparticles, in Elementary Particles and the Laws of Physics, The 1986 Dirac Memorial Lectures by R.P. Feynman and S. Weinberg, (Cambridge University Press, Cambridge, 1987).

[12] O.M.P. Bilaniuk, V.K. Deshpande e E.C.G. Sudarshan, "Meta" Relativity, Am. Journ. Phys., 30, p. 718-723, (1962).

[13] F. Catoni et Al., The Geometry of Minkowski Space-Time, (Springer Briefs in Physics, 2011).
[14] J. Vaz Jr., A Álgebra Geométrica do Espaço-tempo e a Teoria da Relatividade, Rev. Bras. Ens. Física, 22, p. 5-31, (2000).

[15] R.C. Tolman, The Theory of Relativity of Motion, (Berkeley, 1917).

[16] A. Einstein, Über die vom Relativitätsprinzip geforderte Trägheit der Energie, Ann. d. Phys. 23, p. 371-384, (1907).

[17] D. Bohm, The Special Theory of Relativity, (New York, 1965).

[18] E. Recami, The Tolman 'antitelephone' paradox: It's solution by tachyon mechanics, Lett. Nuovo Cim. 44, p. 587-593, (1985).

[19] E. Recami, Tachyon kinematics and causality: A systematic, thorough analysis of the tachyon causal paradoxes, Found. Phys., 17, p. 239-296 (1987).

[20] R.L. Dawe, K.C. Hines, The Physics of Tachyons I. Tachyon Kinematics, Aust. J. Phys. 45, p. 591-620, (1992).

[21] E.C. de Oliveira, W.A. Rodrigues Jr., Soluções Superluminais de Enegia finita das Equações de Maxwell, Tend. Mat. Apl. Comput., 3, p. 165-171, (2002).

[22] E. Recami, M.Z. Rached, Localized Waves: A not-so-short Review, Advances in Imaging \& Electron Physics, 156, p. 235$355,(2009)$.

[23] E. Recami, M. Fracastoro-Decker, W.A. Rodrigues Jr., Táquions, Revista Ciência Hoje, 5, n. 26, p. 48-59 (1986); E. Recami, M.Z. Rached, Mais velozes que a luz? Revista Ciência Hoje, 29, n. 170, p. 20-25 (2001). 